\title{
CROATICA CHRISTIANA PERIODICA
}

\author{
ČASOPIS INSTITUTA ZA CRKVENU POVIJEST \\ KATOLIČKOGA BOGOSLOVNOG FAKULTETA SVEUČILIŠTA U ZAGREBU
}

God. XLV.

Zagreb, 2021.

Broj 87

\section{rasprave i prilozi}

UDK 272-523.6(497.16Bar)“15”(091) 272-9(497.16Bar)“15”

27-36AND

Izvorni znanstveni rad

Primljeno: 5. lipnja 2020.

Prihvaćeno za objavljivanje: 4. prosinca 2020.

\section{SAMOSTAN SV. ANDRIJE U BARU (16. stoljeće)}

\author{
Savo MARKOVIĆ \\ Barska plovidba \\ U1. M. Boškovića 18/51, 85000 Bar, Crna Gora \\ maritime@t-com.me
}

Na osnovu arhivskih podataka i istoriografije iznosi se argumentacija u prilog tvrdnji da je crkva sv. Venerande u Starom gradu Baru zapravo pripadala samostanu dumni sv. Andrije. Temeljem nalaza arheoloških istraživanja i komparativnog metoda nastoji se rekonstruisati izgled crkve $i$ samostanskog kompleksa smještenog uz zidine urbanog prostora koji je predstavljao sastavni dio sakralnog horizonta nadbiskupskog sjedišta. Egzemplarno su analizirana punomoćja jedne redovnice iz Bara. Radom se predlaže preimenovanje titulara samostanske crkve u sv. Andriju.

KLJUČNE RIJEČI: samostan, crkva, kult, crkveni redovi, benediktinke, klarise, 16. stoljeće.

\section{Uvod $^{*}$}

Kada se u literaturi navodi barska crkva, čiji je kult u novije vrijeme atribuiran sv. Venerandi, ${ }^{1}$ pretpostavlja se da je pripadala samostanu ${ }^{2}(» t h e$ hypothetical Dominican

* Rad je napisan na crnogorskom jeziku

1 Ovu nesigurnu atribuciju kulta, upućujući na samostan redovnica sv. Andrije, potenciram u: Savo MARKOVIĆ, Stanovništvo srednjovjekovnog Bara, Perast, 2014., str. 806-807. Đ. Bošković je uistinu atribuciju tog kulta svugdje označio upitnikom u: Đurđe BOŠKOVIĆ, »Istraživački, arheološki i konzervatorski radovi u Starom Baru 1951-1955 godine«, Zbornik zaštite spomenika kulture, knj. VI-VII, Beograd, 1955-56., str. 201, 203, $204,208$.

2 »Po svojoj osnovi, jednostavnom rešenju i uprošćenim oblicima arhitektonskih elemenata koji se na njoj nalaze, može se pretpostaviti da je crkva pripadala dominikancima...«, Đurđe BOŠKOVIĆ, Stari Bar, Beograd, 1962., str. 38. Đ. Bošković daje precizan opis crkve na str. 36-40. 
monastery«), ${ }^{3}$ čiji se kompleks takođe određuje, na oko $900 \mathrm{~m}^{2}$, udaljen 60-70 m sjeverno od nekadašnje katedrale sv. Đura. ${ }^{4}$ Nadbiskup Marko Giorga navodi 1697. godine da se tako intitulirana crkva ( $s v$. Venerande) nalazila unutar gradskih zidina. ${ }^{5}$ Međutim, njegovi prethodnici Marin Bizzi (1610.) i Andrija Zmajević (1671.) crkvu tog kulta smještaju izvan, tj. podalje - oko milju od grada. ${ }^{6}$ Crkvu (»vel sacella«) S. Venerande u Baru pominje i Daniele Farlati, odnosno Jacobus Coleti. ${ }^{7}$

Jednobrodna gotička crkva s kraja 14 . ili iz prve polovine 15 . vijeka ${ }^{8}$ nalazi se u organskom sklopu sa susjednim građevinama, s apsidom okrenutom prema sjeveru. Njen zapadni, bočni, koji je i fasadni zid, rađen je od precizno otesanih kvadera krečnjaka u precizno postavljenim horizontalnim redovima. ${ }^{9}$ Još 1879/80. Pavle Apolonovič Rovinski navodi da je na širinu crkve od oko $8 \mathrm{~m}$ apsida zauzimala više od $5 \mathrm{~m}$, a da je crkva dugačka oko $12 \mathrm{~m} .{ }^{10}$ Ističe se da je prvobitno bila pokrivena drvenom krovnom konstrukcijom. ${ }^{11}$ Tokom 1954. godine na crkvi su obavljeni zamašniji konzervatorski radovi, a njena unutrašnjost je potpuno raščišćena. ${ }^{12}$ Ipak, indikativno je koliko je brzo, ako je suditi prema jednom istorijskom izvoru, usahlo sjećanje na tu samostansku ustanovu. Barski nadbiskup Marko

3 ıseries of rooms hypothetically linked with the property of the church and then of the likely Dominican monastery.«; »This area had been hypothetically identified as an estate of the nearby church of St. Veneranda (Bošković 1962, n. 48, str. 320) that was believed to belong to the Dominican monastery. « Sauro GELICHI, »Introduction. The project and the strategy«; idem, »Stari Bar. The archaeological evidence and the settlement during the ages.", The archaeology of an abandoned town, The 2005 Project in Stari Bar, (by Sauro GELICHI), Firenze, 2006., str. 17, 29, 31; »hypothetical monastic complex«; Fulvio BAUDO - Diego CALAON - Erica D'AMICO, »From monastery (?) to Ottoman house. The excavation of archaeological area 45«, The archaeology of an abandoned town, str. 96.

$4 \mathrm{U}$ tom radu priložena slika određuje »hypothetical monastic complex«, koji se, prema istraživanjima Đ. Boškovića, povezuje s objektima numerisanim brojevima 43, 44, 45 (148,81 m nad morem), 46, 47, 48 i 49. » The traditional interpretation on the origin of this religious building is linked to the identification of the church dated to the $14^{\text {th }}-15^{\text {th }}$ century as belonging to the late medieval Dominican monastery. « F. BAUDO D. CALAON - E. D'AMICO, »From monastery (?) to Ottoman house «, str. 83, 89.

5 Šerbo RASTODER, »Izvještaj Marka Giorga o Barskoj nadbiskupiji 1697.«, Petar PERKOLIĆ (prev.), Istorijski zapisi, god. 57, br. 1-2, Podgorica, 1994., str. 159

6 »ecceto la chiesa di s. Elia sudeta dentro, e fuori della Madonna, e di santa Veneranda, con alcun altre puoche per le ville della diocesi lasciate dai Turchi per l' uso dei Cristiani.«; »Turaka, koji nam više nisu dozvoljavali držati misu u preostaloj kapeli, kao ni u ostalim crkvama u varoši, osim u kapeli sv. Venerande, oko milju udaljenoj od grada.« Franjo RAČKI, »Izvještaj barskoga nadbiskupa Marina Bizzia o svojem putovanju god. 1610. po Arbanaskoj i Staroj Srbiji«, Starine JAZU, knj. 20, Zagreb, 1888., str. 65; Savo MARKOVIĆ, »Prvi Izvještaj Andrije Zmajevića o Barskoj nadbiskupiji Sv. kongregaciji za širenje vjere: godina 1671.«, Istorijski zapisi, god. 71, br. 1-2, Podgorica 1998., str. 214.

7 Daniele FARLATI - Jacobus COLETI, Illyrici Sacri tomus septimus, Venetiis, MDCCCXVII., str. 12; »The identification of the chuch with St. Veneranda and its connection with the Dominican buildings is suggested by Bošković which is in turn based on Farlati (...)«. F. BAUDO - D. CALAON - E. D'AMICO, »From monastery (?) to Ottoman house «, str. 83.

8 »Bar«(A. Sić.), Likovna enciklopedija Jugoslavije, sv. 1, Žarko DOMLJAN (ur.), Zagreb, 1984., str. 70; »Bar« (R.), Enciklopedija hrvatske umjetnosti, sv. 1, Žarko DOMLJAN (ur.), Zagreb, 1995., str. 49.

9 Kvaderi $15-30 \mathrm{~cm}$ visine često se približavaju kvadratu. Na sličan način rađen je i južni zid crkve, na kojem se takođe nalazi portal. Đ. BOŠKOVIĆ, Stari Bar, str. 38.

${ }^{10}$ Pavel Apolonovič ROVINSKI, Crna Gora u prošlosti i sadašnjosti, tom IV, Cetinje - Sr. Karlovci - Novi Sad, 1994., str. 471.

11 Đ. BOŠKOVIĆ, Stari Bar, str. 36.

12 Pored raščišćavanja velikih »rezervoara za ulje ili žito (?)«, zazidana je jedna velika rupa u istočnom zidu, učvršćen svod nad apsidom i poduhvaćeni lučni tesanici na dva prozora zapadnog zida. Đ. BOŠKOVIĆ, »Istraživački, arheološki i konzervatorski radovi u Starom Baru 1951-1955«, str. 204, 207, 208; »whereas the churches of St. Veneranda (...) are heavily restored (...)«, Fulvio BAUDO, »Archaeology of masonry in 
Giorga navodi 1697. godine da se samostan monahinja nalazio unutar gradskih zidina, ali se već tada nije bila »sačuvala uspomena kojeg su reda i pravila bile, ni kojemu je svecu bila posvećena njihova crkva, koja je sada svedena na konobu, a samostan u stan nevjernika $\ll^{13}$. Na osnovu dalje iznesenih podataka ta će se manastirska institucija nazivati samostanom sv. Andrije, a ovim radom se predlaže takvo preimenovanje odnosne crkve.

\section{Položaj i vanjska obilježja samostanske crkve sv. Andrije}

Obilježje te crkvene građevine, osim orijentacije oltarskog prostora prema sjeveru (»izuzetno među barskim crkvama«) ${ }_{1}^{14}$ zapravo predstavljaju tri gotičke ${ }^{15}$ monofore na podužnoj zapadnoj fasadi, ${ }^{16}$ dok je njena rozeta, koja je ostala bez unutrašnjih ukrasa, smještena na krajnjoj južnoj strani. Kružna rozeta sadrži profil sa ozupčanom trakom, ukazujući na skulpturalni prijelaz ka ranorenesansnim oblicima. ${ }^{17}$

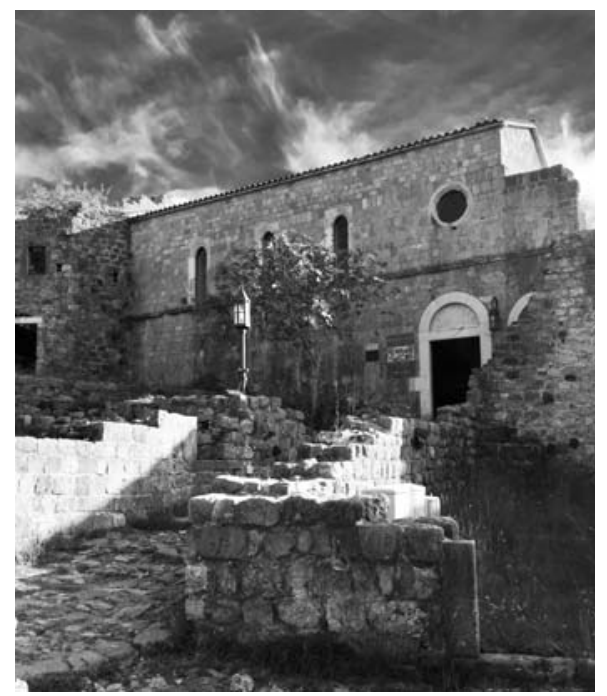

Sl. 1. Fasada crkve sv. Andrije, Stari grad Bar (photo: Savo Marković, 2017.)

Stari Bar«, Stari Bar, The Archaeological Project 2004. Preliminary Report, Sauro GELICHI - Mitja GUŠTIN, Firenze, 2005., str. 32.

13 »svedena $u$ konobu« navedeno je u prijevodu koji mi je ustupio pok. barski nadbiskup Petar Perkolić (riječi date italicom su u rukopisu, nad prekriženim, otkucanim tekstom). U objavljenom tekstu vizitacije stoji: »pretočena u kafanu (točionicu) «; Š. RASTODER, »Izvještaj Marka Giorga o Barskoj nadbiskupiji«, str. 159.

14 Đ. BOŠKOVIĆ, Stari Bar, str. 38.

15 Poimanju gotičke forme ključ je u tipu crkava s uskim i visokim prozorima oštro završenog luka, koji ritmički raspoređeni na oplošju golemih prostorno jednostavnih lađa snaže zamisao vertikala svojstvenih zakonima stila. Igor FISKOVIĆ, »O unutrašnjem uređenju samostanskih crkava na istočnoj obali Jadrana«, Prilozi povijesti umjetnosti u Dalmaciji, god. 39, br. 1, Split, 2005., str. 255.

16 »Tri izdužena gotska prozora završena su lako prelomljenim lucima. Njihovi su okviri spolja jače, a iznutra slabije koso zasečeni prema unutrašnjosti.«Đ. BOŠKOVIĆ, Stari Bar, str. 38.

17 Ibid. 
Fasadni (zapadni) zid crkve podionim je vijencem razdijeljen u dvije zone. ${ }^{18}$ Nastavlja se prema jugu, naslanjajući se na objekat koji je Đ. Bošković označio brojem $46 .{ }^{19} \mathrm{Na}$ tom dijelu zida nalazi se nešto manji portal kojim se ulazilo u samostanski kompleks, sličan portalu kojim se ulazi u crkvu. ${ }^{20}$ Profilovana konzola nalazila se i na južnom čeonom zidu. ${ }^{21}$

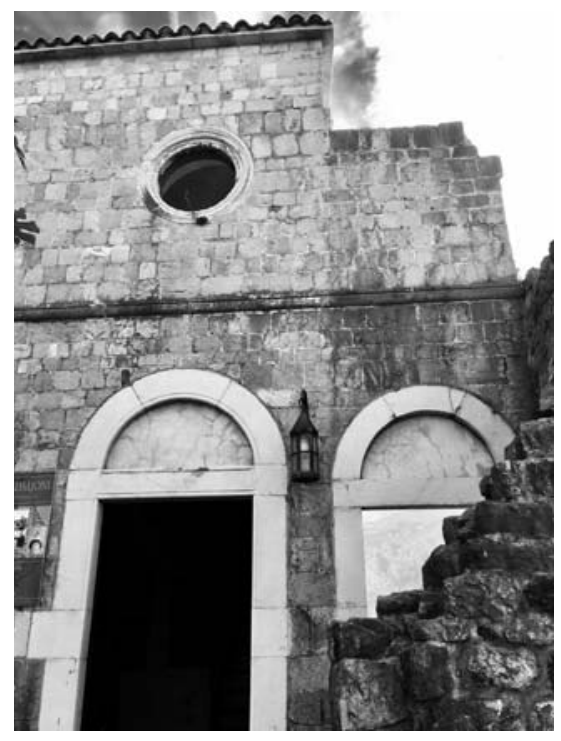

Sl. 2. Bočni zid sv. Andrije s portalima kojima se ulazilo u crkvu i samostanski kompleks

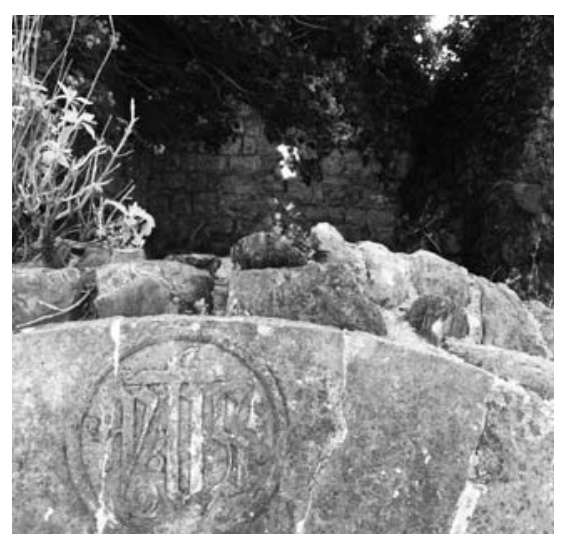

Sl. 3. Pogled u unutrašnjost samostanskog kompleksa (photo: S. Marković, 2017.)

\footnotetext{
18 Ibid.

19 Ibid.

20 Ibid.

21 Ibid.
} 


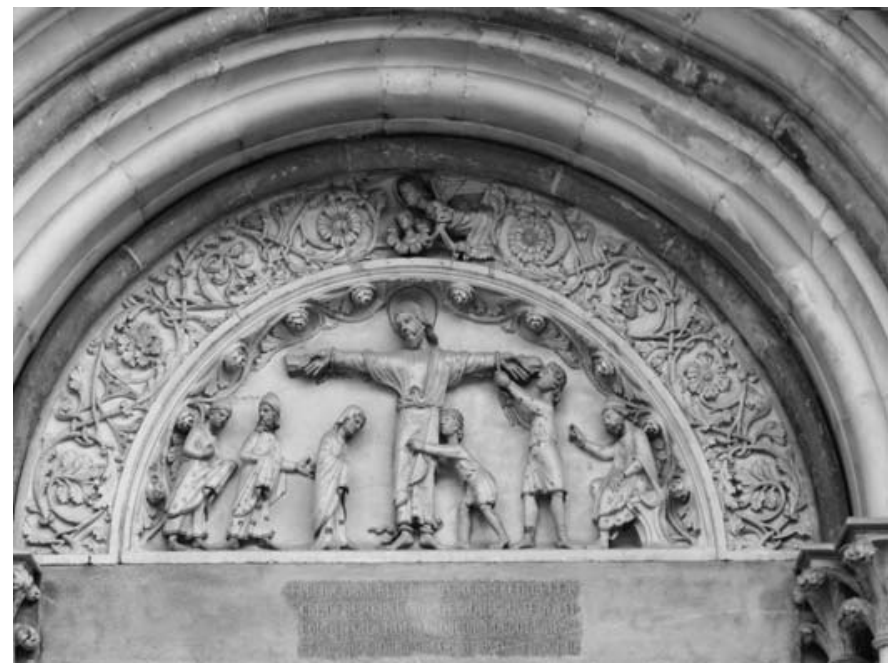

Sl. 4. Mučeništvo sv. Andrije, reljef Benedetta Antelamija (oko 1220/25.) u luneti portala crkve sv. Andrije u Vercelliju ${ }^{22}$

Postavlja se pitanje kako je izgledao portal samostanske crkve sv. Andrije, odnosno sv. Venerande? »Portal, sudeći prema tragovima u zidu, bio je dosta bogato razvijen, sa polukružnom arhivoltom, koja je obuhvatala timpan. «23 Prikazujući epizodu iz života, možda scenu mučeništva sv. Andrije, u luneti crkvenog portala (i na luku koji je uokviruje), najvjerovatnije se nekada nalazio živopis, odnosno skulpturirana predstava. »Portal na južnom zidu kasnije je zazidan. « $^{24}$

Monogram IHS ispisan goticom, s krstom u kružnici, najvjerovatnije iz 15. vijeka, prizidan (!) u samostanskom kompleksu, upućivao bi na franjevačku pobožnost prema Presvetom Imenu Isusovu. U liturgijskoj umjetnosti monogram je prikazivan na modroj podlozi. Predstavlja tri početna slova Isusova imena na grčkom [»IH $\Sigma \ll-\mathrm{IH} \Sigma \mathrm{OY} \Sigma$ - IHSOYS - Iesous: I (iota), H (eta) i S (sigma - $\Sigma$, na latinskom kao S)]. Srednje slovo završava s krstom iznad. Pobožnost prema Hristovu imenu se u 15. vijeka raširila preko sv. Vinka Ferrera, sv. Ivana Kapistrana i sv. Bernardina Sijenskog. »Oni su, kao i dominikanci, osnivali društva i bratovštine Svetog imena, i propovijedanjem širili ovu pobožnost. « ${ }^{25} \mathrm{~Sv}$. Ignacije je 1541. godine ovim monogramom predstavio novi red,

\footnotetext{
22 Privatno vlasništvo autora Laurom, 11. 11. 2009. [Di Laurom - Opera propria, CC BY-SA 3.0, https://commons.wikimedia.org/w/index.php?curid=8763988 (zadnje posjećeno 5. 5. 2018.)].

${ }^{23}$ Đ. BOŠKOVIĆ, Stari Bar, str. 38.

24 Ibid.

25 »SStovanje Imena Isusova proširili su po Italiji i cijeloj zapadnoj Europi Bernardin Sijenski i njegov učenik Ivan Kapistran. Pod utjecajem Bernardina de Bustisa papa Inocent VIII. (1484. - 1492.) dopustio je franjevcima godišnje slavlje, na dan 14. siječnja, blagdana Imena Isusova. Konventualci su običavali slaviti taj blagdan zajedno s dijecezanskim svećenstvom druge nedjelje nakon Navještenja sve dok papa Pio X. nije protegnuo ovaj blagdan na cijelu Crkvu i smjestio ga između blagdana Obrezanja našeg Gospodina i Navještenja. Godine 1530. papa Klement VII. dopustio je službu koju je za časoslov napisao Bernardin de Bustis.«
} 
Družbu Isusovu. Sv. Bernardin (1380. - 1444.) je u propovijedima podsticao narod na pouzdanje u Isusovo ime i na stavljanje simbola IHS na ulazna vrata gradova i kuća. O apotropejskoj moći Isusova imena propovijedao je u Firenci 1424. godine ${ }^{26}$. Posmatran u društvenom kontekstu, postavljen na(d) ulazna kućna vrata, monogram se sagledava unutar antropološkog koncepta liminalnosti. ${ }^{27}$ Vodeći računa o kolektivnim predstavama, mentalitetu i strahu te s obzirom na praksu s apotropejskom ulogom, ističe se da fasada građevine dijeli vanjski od unutarnjeg prostora, a kada je o crkvama riječ, vjernike i nevjernike. ${ }^{28} \mathrm{Na}$ ulaznim vratima, mjestima jakog simboličkog značenja kakva su sredine nadvratnika ili okviri prozora, Hristov monogram IHS obavijen kružnicom, koji zaziva Isusa, bio je iskaz religioznosti u funkciji zaštite od kuge, drugih nevolja i različitih prirodnih nepogoda, kao i od magije. ${ }^{29}$

Postavlja se pitanje sličnosti arhitektonskih elemenata sa onima u drugim konventima. »Svečana gotička fasada« crkve, koja bi se mogla pripisati vremenu Balšića, izgrađena od pažljivo složenih tesanika, "po načinu gradnje i po otvorima prozora « na zapadnom podužnom zidu liči na glavne dubrovačke samostane. ${ }^{30} \mathrm{U}$ tipološki dorađenoj i stilski sređenoj arhitekturi crkava u primorskim samostanima mnogo se na estetskom planu postizalo rasporedom prozora. ${ }^{31}$ Mahom tokom razdoblja vladavine gotike, posebno se »simetrijom težilo uspostaviti ideale stila vezane za učinke svjetla koje uvođeno kroz visoke a uske otvore nalik prorezima zida stvara dojam univerzalne, bazično vjerske metafizike $\ll^{32}$. Postavljani na ravnoj oplati, pravilnom su ritmičnošću omogućili cjelovita i ujednačena sagledavanja geometrijski strogih, a vrlo visokih gradnji, dok je poremećaj reda razmještaja otvora moguće istumačiti u odnosu na ustroj prostora s visokim pregradama. ${ }^{33}$ Transmisija sistematskih arhitektonskih rješenja mogla se ponajprije dogoditi osnivanjem nove kuće od redovnica koje su »kolonizovale« drugu kuću. ${ }^{34} \mathrm{U}$ opisu crkve u Baru ističe se i da je između njenih bočnih zidova »ubačena polukružna

Danijel PATAFTA, »Franjevački utjecaj na liturgiju i pučku pobožnost«, Služba Božja, god. 57, br. 4, Split, 2017., str. 452-452.

${ }^{26}$ U Šibeniku primjerice, Nikola Firentinac 1464. g. radi na kapeli sv. Bernardina Sijenskog. Antonia VODANOVIĆ, »Liminalnost u arhitekturi: praksa uklesavanja Kristovog monograma na portale ranonovovjekovnih šibenskih kuća«, Kamen na cesti: granice, opresija i imperativ solidarnosti, Radovi sa znanstvenog skupa »Marija Jurić Zagorka - život, djelo, naslijeđe / Preko granica: opresija i imperativ solidarnosti« održanog 25. - 26. studenog 2016. u sklopu 10. Dana Marije Jurić Zagorke, Lada ČALE FELDMAN Lidija DUJIĆ - Maša GRDEŠIĆ - Renata JAMBREŠIĆ KIRIN - Anita DREMEL - Nataša MEDVED (ur.), Zagreb, 2017., str. 140.

27 A. VODANOVIĆ, »Liminalnost u arhitekturi: praksa uklesavanja Kristovog monograma na portale«, str. 134.

${ }^{28}$ Ibid., str. $134-135$.

${ }^{29}$ Ibid., str. 136, 138-142.

30 »Pretpostavlja se da je u pitanju crkva dominikanskog manastira, nastala krajem 14. ili početkom 15. vijeka.« Vojislav ĐURIĆ, »Umjetnost«, Istorija Crne Gore 2, tom 2, Sima ĆIRKOVIĆ - Ivan BOŽIĆ - Dimitrije BOGDANOVIĆ - Vojislav ĐURIĆ (ur.), Titograd, 1970., str. 434.

31 I. FISKOVIĆ, »O unutrašnjem uređenju samostanskih crkava«, str. 255.

32 Ibid.

${ }^{33}$ Unutar gotičkog sistema, nesumnjivo su za pregrade uputna bočna vratašca na spratu. Ibid.

${ }^{34}$ Caroline BRUZELIUS, »Nuns in Space: Strict Enclosure and the Architecture of the Clarisses in the Thirteenth Century«, Clare of Assisi: A Medieval and Modern Woman, Ingrid PETERSEN (ur.), New York: St. Bonaventure, 1996., str. 57. 
apsida $\ll^{35}$. Mnogi su konventi utemeljeni u već postojećim zgradama, ${ }^{36}$ koje su prema konfiguraciji više ili manje prilagođavane potrebama klauzure i reda uopšte. ${ }^{37} \mathrm{U}$ svakom slučaju, još na kraju 13. vijeka bilo je vrlo teško identifikovati i opisati arhitekturu ženskih redovničkih zajednica kao karakteristično cistercitsku, onu koja je obilježavala klarise, ili benediktinsku. ${ }^{38}$

\section{Obilježja crkvenog interijera}

Apsida samostanske crkve vjerovatno je građena u vrijeme podizanja bočnih zidova, ali od grublje obrađenih tesanika; prislonjena je uz, prethodno podignuti, zapadni zid. ${ }^{39} \mathrm{Na}$ istočnom dijelu čeonog zida apside vidljiv je posvetni medaljon s oblikom krsta. ${ }^{40}$

U istočnom zidu crkve, sjeveroistočno prema objektu br. 49, nalazi se otvor pravougaonog oblika sa kosim padom prema unutrašnjosti trougaonog prostora između apside i obimnih zidova, strana pokrivenih crvenim malterom. ${ }^{41}$ Pretpostavlja se da je mogao služiti za odvod vode, »ali se ne vidi jasno ni odakle je voda išla ni kuda je odlazila « ${ }^{42}$. O spremištima izgrađenim u podu crkve govori se pri razmatranju vodosnabdijevanja konventa.

Na bočnim zidovima, na južnom čeonom zidu crkve i na istočnom dijelu čeonog zida apside sačuvao se dio freskomaltera sa sedam očuvanih, vidljivih medaljona, od vjerovatno dvanaest kružnih grčkih posvetnih krstova, koji se sličnošću dovode u vezu sa znamenjem kotorske crkve sv. Ane. ${ }^{43}$ Krstovi su upisani u krug, na malteru, »na kome su bili izrađeni crvenom bojom na okerastom pozađu. Malter je krupnozrn, a u njemu je bilo i isitnjene slame. $\ll^{44}$

Priloženi su snimci posvetnih krstova uporedivih po izrazitijoj sličnosti sa opisanima:

\footnotetext{
${ }^{35}$ V. ĐURIĆ, »Umjetnost«, Istorija Crne Gore 2, tom 2, str. 434.

36 Arheološkim istraživanjima sprovedenim 2005. godine pokazalo se da je hipoteza Đurđa Boškovića o dvije monaške ćelije u susjednom objektu br. 45 netačna, jer taj prostor nije sadržao stratifikaciju stariju od otomanskih vremena. Još krajem 16. i u 17. vijeka veći dio tog prostora bio je vrt, odnosno dvorište omeđeno zidovima od vanjskih saobraćajnica, a prostorije na prvim spratovima objekata označenih brojevima 47 , 48, kao i 46 i 43, bili su dovoljne za potrebe života porodice jednog »of the officers of the new Ottoman government« (ukoliko su bile u istom vlasništvu). S. GELICHI, »Introduction«, str. 17; F. BAUDO - D. CALAON - E. D'AMICO, »From monastery (?) to Ottoman house «, str. 83, 95, 96.

${ }^{37}$ C. BRUZELIUS, »Nuns in Space: Strict Enclosure and the Architecture of the Clarisses«, str. 57.

38 Ibid.

39 Zid stambene zgrade br. 49 je potpuno pravilno obrađen, a imao je i jedan otvor koji je gledao prema objektu 48, koji je naknadno zazidan. Đ. BOŠKOVIĆ, Stari Bar, str. 38.

40 Ibid., str. 40

41 Ibid., str. 38.

${ }^{42}$ U neposrednoj blizini na istom istočnom zidu kasnije je izgrađen jedan grubo ozidan otvor, »koji je izgleda vodio u sprat susedne zgrade 49 «, Ibid., str. 38 . Za evropske prostore poznato je da su recluse obično živjele u manjoj izbi s jednim ulazom iz crkve, dok o pristupu jednom takvom dubrovačkom rekluzoriju svjedoči arhivski dokument. Nella LONZA, »The houses of recluse (reclusoria) in the urban and suburban setting of medieval Dubrovnik«, Scripta in honorem Igor Fisković, Zbornik povodom sedamdesetog rođendana, Miljenko JURKOVIĆ - Predrag MARKOVIĆ (ur.), Zagreb - Motovun, 2016., str. 307.

${ }^{43}$ Rajko VUJIČIĆ, Studije iz crnogorske istorije umjetnosti, Čedomir DRAŠKOVIĆ (ur.), knj. 41, Cetinje, 1999., str. 74.

44 Đ. BOŠKOVIĆ, Stari Bar, str. 40.
} 

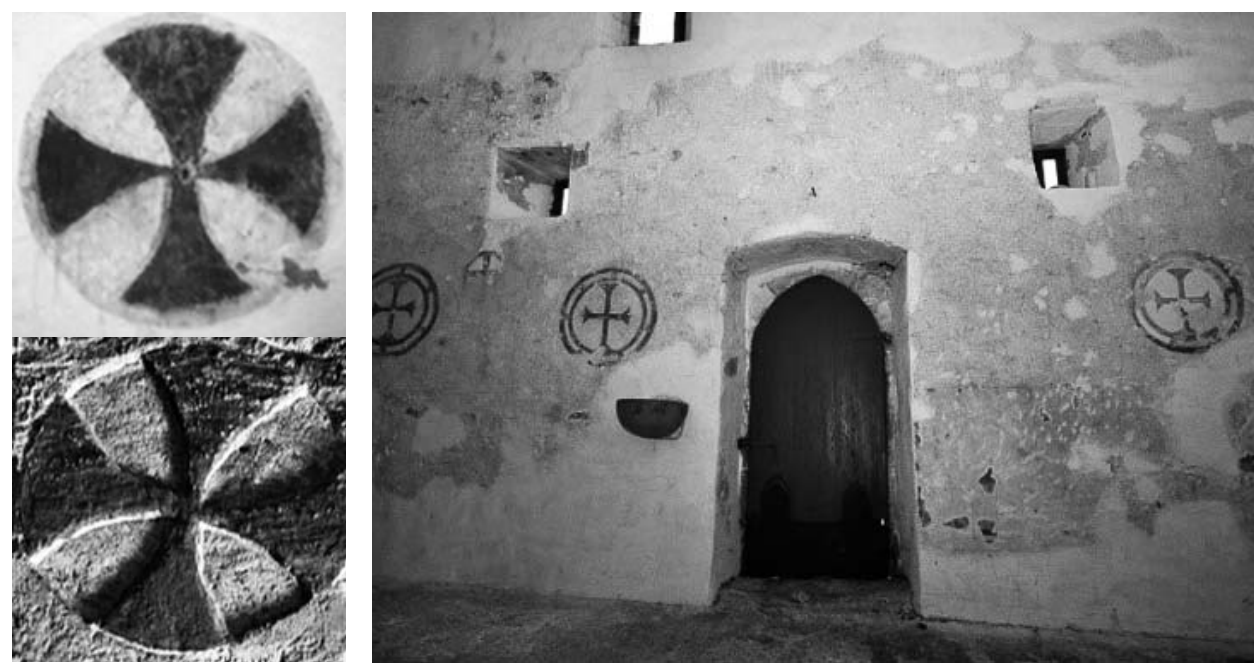

SI. 5. - 7. Posvetni krst na zidu crkve St. Andrew (14. vijek) u Langfordu, Engleska; ${ }^{45}$ posvetni krst u crkvi Sain-Vaast, Vilac, Dordogna, Francuska; tri posvetna i sunčani krst (manji) na bočnom zidu crkve sv. Antuna Opata u Roču, Istra, Hrvatska ${ }^{46}$
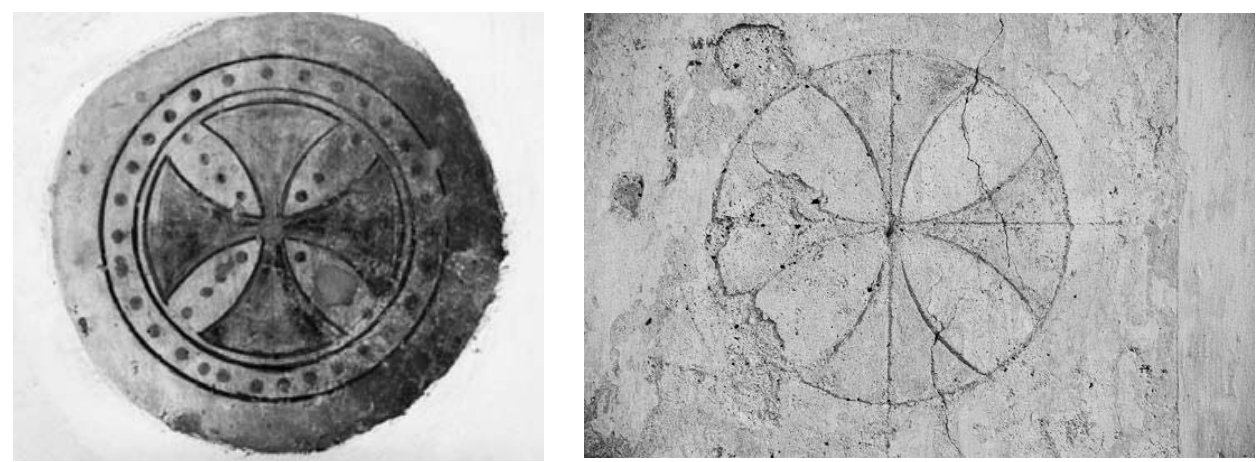

SI. 8. - 9. Posvetni krstovi u engleskim crkvama: na zapadnom zidu crkve St. Margaret, Hardley, Norfolk; ${ }^{47}$ Thompson, Norfolk ${ }^{48}$

$45 »$ The United Benefice of St Mary's, Henlow, and St Andrew's, Langford«, http://www.langfordchurch.org. uk/images/standrews-mediaevalcross150.png ((zadnje posjećeno: 9. 5. 2018.).

${ }^{46} \mathrm{https} / / /$ commons.wikimedia.org/wiki/File:Villac_\%C3\%A9glise_croix_cons\%C3\%A9cration_(1)_cropped. JPG\#/media/File:Villac_\%C3\%A9glise_croix_cons\%C3\%A9cration_(1)_cropped.JPG (zadnje posjećeno: 9. 5. 2018.); Ljubomir ŠKRINJAR, »Roč - ,Krasna zemljo, Istro mila' «- - Portal Hrvatskoga kutirnog vijeća, Objavljeno: 9. lipnja 2009., https://www.hkv.hr/reportae/lj.../4612-reportaa-ro--qkrasna-zemljo-istro-mila. html (zadnje posjećeno: 5. 5. 2018.).

47 https://upload.wikimedia.org/wikipedia/commons/3/32/St_Margaret\%27s_church_-_consecration_cross_ on_west_wall___geograph.org.uk___1339028.jpg (zadnje posjećeno: 12. 5. 2020.).

48 Consecration Cross «; »A geometric cross shape, usually enclosed within a circle, painted on interior and/or exterior walls of medieval churches and sometimes on the altar itself. These stylised crosses were anointed with oil as part of the ceremony officially consecrating the church. Many medieval consecration crosses survive, for example at Ashby St Ledger, Northamptonshire, and Thornham Parva, Suffolk, to name only 


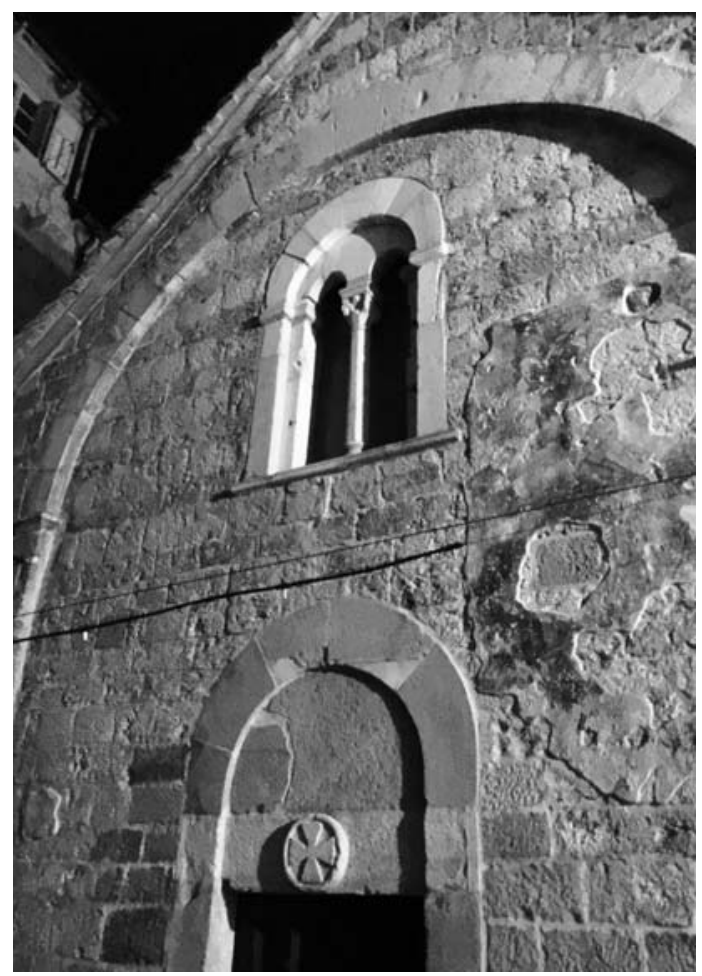

SI. 10. Sv. Ana u Kotoru, detalj pročelja (photo: S. Marković, 2018.)

Crkva sv. Andrije (sv. Venerande) bila je oslikana na suvo (»al secco $\ll){ }^{49}$ »Zidovi su kasnije, poslije izrade medaljona, omalterisani krupnozrnim malterom bez pleve. $\mathrm{Na}$ hrapavoj zrnastoj površini toga maltera naziru se ostaci živopisa, naročito na istočnom bočnom zidu. Sačuvane su još crvena, svetlo okerna i tamno plava boja. U visini donje ivice konzola vidi se crvena bordura, a ispod tri, svetlom okernom bojom naslikana stuba, od kojih jedan ima okerast, a drugi crven kompozitni renesansni kapitel, gledan odozdo, iskosa. Ugrebene linije u površinu zida pokazuju da su iza stubova, u organskoj vezi sa njima, bili predstavljeni i stupci sa vencima čiji su bočni delovi perspektivno zakošeni. Između stubaca bile su izrađene arkade, okerne, na crvenom pozađu. U jednoj, severnoj, nešto bolje očuvanoj, nazire se okerasti nimb, crvena podloga za svetačku glavu i tamno plava podloga za odoru. U drugoj, desnoj arkadi, bio je, u sredini, ukopčan medaljon za osvećenje. Po nagoveštaju perspektive u rešavanju stubaca i kapitela i po strukturi maltera reklo bi se da je živopis pripadao kraju 15. ili možda čak i prvoj polovini 16. veka. U doba Turaka bio je prekrečen, tako da i to smeta, pored toga što je jako izbledeo, njegovom tačnijem identifikovanju. $\ll^{50}$ Prikazi svetaca, uokvirenih arkadama i stupcima mogli su se nadovezivati na oltarske menze, služeći im kao retabli; stojeće figure (friz svetaca pod polukružnim arkadama) mogle su biti retabli oltaru sa strane (side altar). ${ }^{51}$ Gledajući na njih, kongregacija je sticala uvid i doživljavala nebesku i zemaljsku crkvenu hijerarhiju.

two of many. There might be a dozen crosses painted around the interior of a church, and as many again on the exterior.« Krstovi označavaju svetost crkve. Obično su smješteni visoko na zidovima i imaju pričvršćenu ploču (zidni svijećnjak) ispod. Illustrated Dictionary of British Churches. Https://www.britainexpress.com/ images/ attractions/editor/churches/Thompson-8121.jpg (zadnje posjećeno: 9. 5. 2018.).

49 Mladen ZAGARČANIN, Stari grad Bar: vodič kroz vjekove, Bar, 2008., str. 42.

50 Đ. BOŠKKOVIĆ, Stari Bar, str. 40.

${ }^{51}$ Cfr.: Justin E. A. KROESEN, »The altar and its decorations in medieval churches. A functionalist approach «, Medievalia: Revista d'Estudis Medievals, 17, Universitat Autònoma de Barcelona, 2014., str. 165-166. 
Radi ikonografske komparacije, dalje su prikazane scene iz apside crkve sv. Roka u Roču (Buzet), Istra.
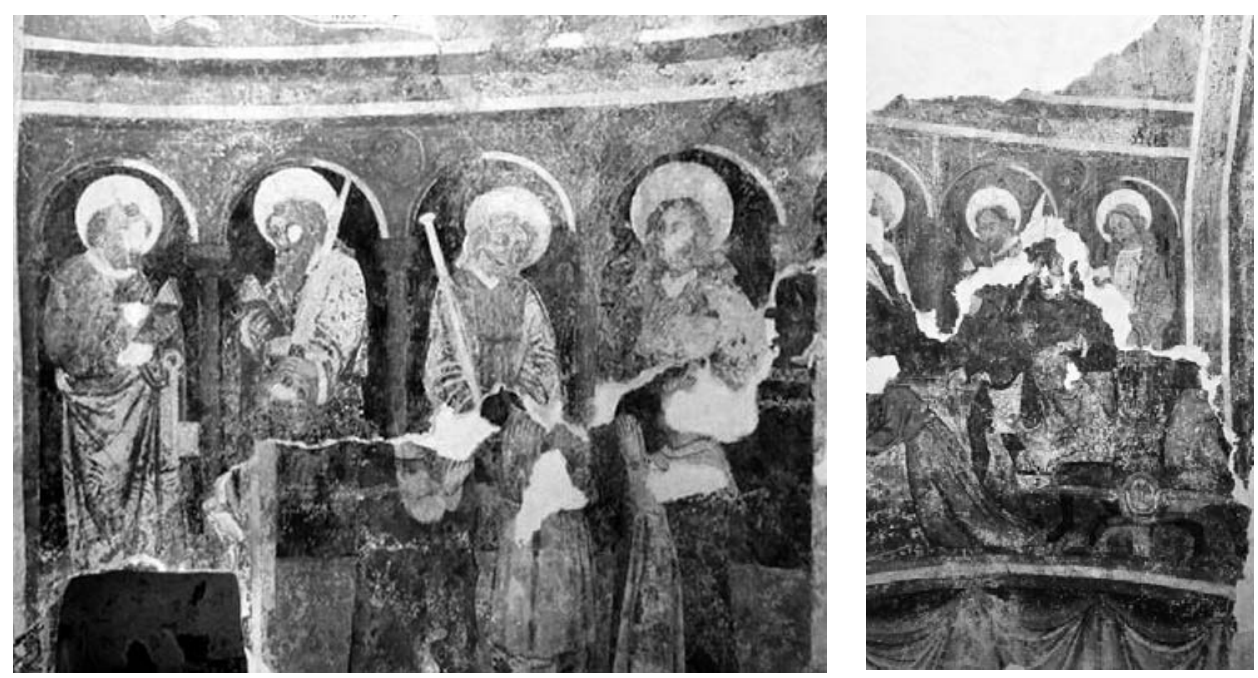

SI. 11. - 12. Freske u Roču (lijeva i desna strana apside sv. Roka), Istra: apsida jednobrodne romaničke crkvice sv. Roka oslikana je s tri sloja gotičkih fresaka iz 14. i 15. st. (preuzete slike objavljene su uz tekst Lj. Škrinjara, »Roč - ,Krasna zemljo, Istro mila' «) $)^{52}$

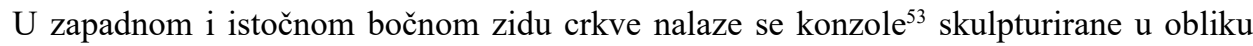
lava,${ }^{54}$ koje su držale »tribinu od drveta, na čije postojanje ukazuje i raspored otvora na zapadnom zidu, odnosno rozeta iznad portala $\ll^{55}$. Đ. Bošković ne navodi potencijalnu namjenu te drvene konstrukcije, ${ }^{56}$ te se pretpostavlja da se radilo o pjevalištu. Uzdignuti hodnicibalatoriji posebno su se upriklađivali za nošenje orgulja. ${ }^{57}$ Međutim, gradnja povišenog

${ }^{52}$ Freske se povezuju »s krugom Ivana iz Kastva čiji se oslici nalaze diljem Istre«. Stariji sloj je iz 14. v. »Od 12 likova apostola, naslikanih u nišama arkada s tamnomodrom pozadinom, danas vidimo samo petoricu. Najbolje se sačuvalo lice apostola Filipa (prvi s desna, odnosno zadnji u nizu).« U gornjem dijelu apside naslućuje se prikaz scene poznate kao Maiestas Domini. U scenama mučeništva u desnom dijelu apside prepoznaje se odsijecanje glave sv. Pavla koji kleči, i raspeće sv. Petra, između kojih je prizor Čuda sv. Jakova. »(...) u gornjem, oštećenijem, možemo naslutiti Krista u slavi. Scenu prepoznajemo po dvjema životinjama sa svicima, lavu i orlu, simbolima evanđelista Marka i Ivana, koji su u društvu vola (Luke) i anđela (Mateja) okruživali prijestolje na kojem je sjedio Krist.« Lj. ŠKRINJAR, »Roč«; »Crkva sv. Roka u Roču«, Istria Culture, www.istria-culture.com/crkva-sv-roka-u-rocu-i183 (zadnje posjećeno: 9. 5. 2018.).

${ }^{53}$ Cfr. »konzolice strehe«; I. FISKOVIĆ, »O unutrašnjem uređenju samostanskih crkava«, str. 241.

${ }^{54}$ M. ZAGARČANIN, Stari grad Bar, str. 42.

${ }^{55} \mathrm{U}$ tursko doba je ubačeno još nekoliko konzola u bočne zidove. Tako da se međuspratnom konstrukcijom građevina pretvorila u stambenu zgradu. Đ. BOŠKOVIĆ, Stari Bar, str. 38.

${ }_{56}$ Balatorij na kraju 15. i u 16. vijeka u Dubrovniku, koji pripada prostoru dvorana, je drveni. Nada GRUJIĆ, »Balatorij u dubrovačkoj stambenoj arhitekturi XV. stoljeća«, Prilozi povijesti umjetnosti u Dalmaciji, god. 37. br. 1, Split 1998., str. 146.

${ }^{57}$ Darovnica crkvi zadarskih dominikanaca iz 1396. g. bilježi: »reparatione ballatorii (...) ubi sunt organa«. Dominikanci u Dubrovniku su 1460. g. približili oltaru stari balatorij, na kojem su bile smještene orgulje. I. FISKOVIĆ, »O unutrašnjem uređenju samostanskih crkava«, str. 251. 
prostora (podijuma) za pjevalište (hor), do kojeg se dolazilo stubama, redovno nad ulazom u crkvu, nasuprot oltaru, svojstvena je kasnijem razdoblju (baroku), ${ }^{58}$ kada se uvode velike orgulje ${ }^{59}$ i pjevački horovi laika. ${ }^{60}$ Galerije nad crkvenom lađom za dobročinitelje, gospo${ } e^{61}$ i sl. nazivane su oratorij, ili mali hor. Ipak, slična građevinska intervencija u crkvi sv. Andrije mogla je uslijediti i prije 1571. godine, ${ }^{62}$ te tako funkcionalna podjela prostora $i$ njegova kultna sadržajnost biti izvorne. ${ }^{63}$

\section{Samostan sv. Andrije i pretpostavke za ustanovu stroge klauzure}

Ukoliko je svetilište sv. Andrije bilo samostanska ustanova stroge klauzure, ona je, uz svoju religijsku komponentu, izolovala i štitila redovnice od dodira s laičkim društvom, od nasilja i upadača. ${ }^{64}$ Univerzalna pravila klauzure za sve pobožne žene objavljena su 1298. godine bulom Periculoso pape Bonifacija VIII. ${ }^{65}$ Njima su utvrđene arhitektonske barijere u vidu rešetki i zaslona, bez obzira na monaški red. ${ }^{66}$ Horovi redovnica mogli su biti smješteni lateralno flankirajući brod ili apsidu, iza oltara, u gornjoj galeriji, ili prostoriji na zapadnoj strani zgrade ${ }^{67}$ Karakteristika takvih crkava je da sestre nisu imale potpun i nesmetan pogled na misu, a često nisu imale nikakav pogled. ${ }^{68}$

Kod klarisa, liturgijsko iskustvo 13. stoljeća sastojalo se od slušanja, prije nego viđenja. ${ }^{69}$ Forma Života sv. Klare iz 1253. godine dozvoljavala je da se platno (zavjesa) ukloni tokom mise. ${ }^{70}$ Regulacije za klarise, kao i Forma Života, naglašavali su važnost tišine u konventu; tako je slušanje mise donosilo posebno iskustvo. ${ }^{71}$

${ }^{58} \mathrm{U}$ crkvi sv. Frane u Zadru uklanjanje pregrade obavljeno je u sklopu njene prve barokizacije iz 1611. g. Ibid., str. $239,241$.

${ }^{59}$ U kasnijim vremenima orguljama su se uobičajili graditi balatoriji prislonjeni visoko uz zapadni zid crkve, iznutra nad ulazom, kako ne bi smetale pogledu i djelotvornije zvukom pratile ceremonije. Locus organorum u dubrovačkoj prvostolnici uspostavom balatorija 1500. g. slijedi premještanje balkona sprijeda nad ulazna vrata. Već je 1615. godine u Dubrovniku dopušteno »fratres S. Francisci in inferiori parte ecclesie possint construere chorum elevatum cum organo«. U baroku se do sredine 17. vijeka u crkvama zadarskih (1632.) i dubrovačkih franjevaca orgulje povećavaju. Ibid., str. 241, 243.

${ }^{60} \mathrm{Cfr}$.: »mjesto prožimanja poluliturgijskih službi sa svjetovnim polovima unutarcrkvenih zbivanja«. Ibid., str. 251.

${ }^{61}$ Dvoetažna galerija je postojala na južnom zidu crkve sv. Dominika u Dubrovniku, namijenjena dubrovačkim plemkinjama pri odvijanju crkvenih slavlja. Ibid., str. 264.

${ }^{62}$ U hvarskoj crkvi franjevaca pregrada je dopunjena pjevalištem kao drvenim mostom nad njom, a takvo je stanje »najvjerojatnije bilo od početka« (1470.). Na sredini balatorija - pjevališta uzdignuto je raspelo. Stube za uzlaz na pregradu morale su biti svinute i usko položene. Ibid., str. 233, 235, 237, 243.

${ }^{63} \mathrm{Ibid}$., str. 238.

${ }^{64}$ C. BRUZELIUS, »Nuns in Space«, str. 55.

${ }^{65}$ Ibid., str. 71.

${ }^{66}$ Prozori ili vrata koji su spajali omogućavali su da se čuje zvuk i dostavi posvećena hostija za pričešće. Ibid., str. 59, 61 .

${ }^{67}$ Takav je primjer u svetilištu San Paolo u Tuscaniji. U S. Sebastianu u Alatriju redovnice su se mogle popeti drvenim stepeništem radi ispovijedi iza zavjese. Ibid., str. 58, 61 .

${ }^{68}$ Kvalitet takvog »dodatka« reflektovao je karakter liturgijskog iskustva redovnica. Ibid., str. 54, 61.

${ }^{69}$ Ibid., str. 61.

${ }^{70}$ Središnji čin liturgije - uzdizanje hostije i dramatična vizuelna alegorija mise (sveta »drama«) - nije bio dostupan ženskoj zajednici: bez vizuelnog udjela, važnost je zadobijalo ono što se čuje. Ibid., str. 61, 64.

${ }^{71}$ Ibid., str. 64, 65 . 


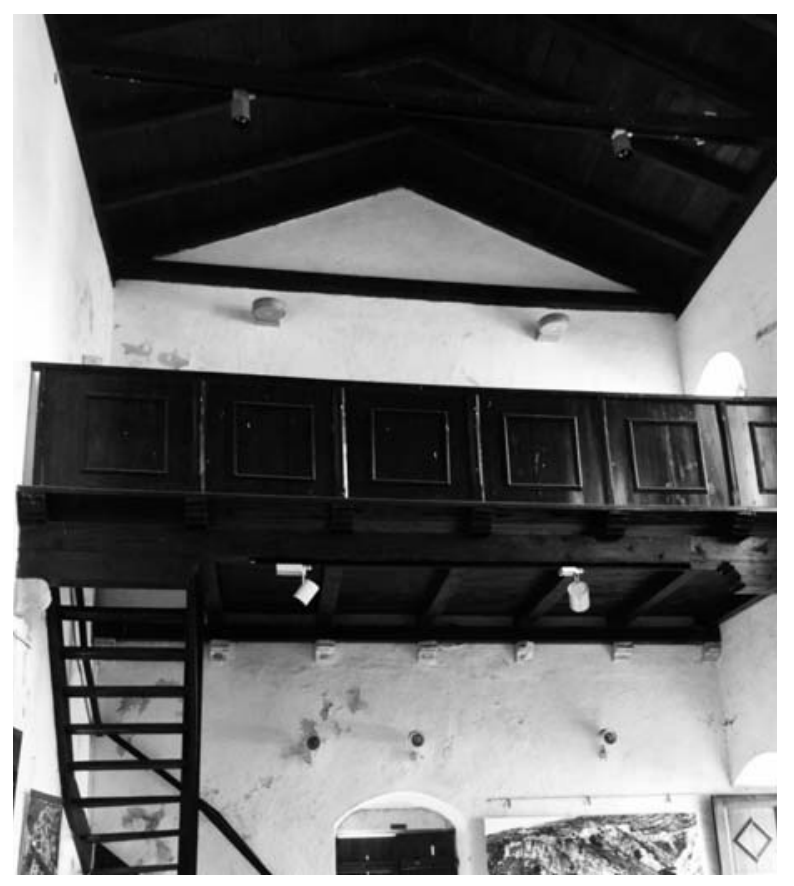

S1. 13. Južna strana crkve sv.

Andrije, Stari grad Bar (photo: S.

Marković, 2017.)

Hijerarhija vizuelnog unutrašnjim zastorima i barijerama (odvajanje redovnica od crkve i oltara) bila je uobičajena $u$ srednjovjekovnim crkvama. $^{72}$ Potkraj 13. vijeka klerici su nastojali da budu odijeljeni od laika, tako da je masa prisustvovala ritualu koji je direktno mogla vidjeti i čuti jedino elita, većinom klerikalna. ${ }^{73}$ Proliferacija subsidijarnih kapela i oltara u velikim crkvama značila je da je često bilo službi svakog dana, idealno tempiranih u različito vrijeme, da se ne poklapaju, tako da je subsidijarni kler dobrim

dijelom imao funkciju da služi takve sekundarne mise. ${ }^{74}$ Prema nekim istraživanjima, hor, više nego što je bio integrisan u oblik crkve, pozicijom je bio analogan anahoretskoj ćeliji pri župnoj crkvi. Kao rezultat toga horovi klarisa rijetko su bili integralni dio plana crkve, koje su koherentnošću tendirale da postoje kao nezavisne, starije građevine. ${ }^{75}$

Vizitacije, godišnje »provjere« redovničkih zajednica, u ženskim kućama obično je izvodio muški nadzornik - opat iz muške kuće istog reda ili lokalni dijecezanski službenik - poštovanje pravila reda provjeravao je tako izvanjac. ${ }^{76}$ Klauzura je većinom bila orijentisana prema ulasku muškaraca ${ }^{77}$ u zajednicu žena, koje su bile odijeljene i od klera. ${ }^{78}$

${ }^{72}$ Crkveni prostor je inače dijelio muškarce i žene, koje su obično zauzimale sjevernu stranu. Ibid., str. 67.

${ }^{73}$ Glavna misa, služena jednom nedjeljno, postajala je uzvišen događaj, slavljen s procesijama i muzikom, što se sredinom 13. vijeka djelimično moglo čuti od laičke javnosti. Ibid., str. 66.

${ }^{74}$ Ibid.

75 Ibid., str. 54.

76 Ibid., str. 55.

${ }^{77}$ Franjevačke redovnice i štićenice koparskog samostana sv. Klare mogle su na osnovu posebne dozvole u govornici (parlatorio), u prisustvu jedne slušateljice (ascoltatrice), ili od nje određene druge redovnice, razgovarati s rodbinom i drugim poznanicima. Zdenka BONIN, »Koprski samostan svete Klare«, Kronika, letnik 51, številka 2, Ljubljana, 2003., str. 137.

${ }^{78}$ U Dubrovniku su muški franjevački i samostan sv. Klare bili blisko povezani, podražavajući prijateljstvo između sv. Franja i sv. Klare. Nedjeljom i praznicima franjevci su dolazili da pjevaju i da se mole u sestrinskoj crkvi. Međutim, redovnici su bili uglavnom pučani iz okoline Dubrovnika i daljih krajeva, a klarise iz istaknutih vlasteoskih rodova. 1434. godine došlo je i do skandala. Iako je slučaj potpadao pod jurisdikciju nadbiskupskog suda, umiješale su se i gradske vlasti. Zdenka JANEKOVIĆ RÖMER, »Nobel Women in Fifteenth-Century Ragusa «, East Central Europe/L'Europe du centre est: Eine wissenschaftliche Zeitschrift, vol. 20-23, part 1, University of Pittsburgh, University Center for International Studies; 
Međutim, muškarci su bili neophodni jer su jedino klerici mogli ispovijedati, služiti misu i podjeljivati euharistiju. ${ }^{79}$ Kao kontemplativni i zatvoreni red, klarise su mogli posjećivati samo rođaci. Bile su omiljene u porodici, ne predstavljajući joj više finansijski teret i bivajući garancijom Božje milosti. ${ }^{80} \mathrm{U}$ decembru 1564., godinu dana nakon završetka Tridentskog koncila, barski nadbiskup Ivan Bruni napisao je pismo kardinalu Borromeu, tražeći njegovu pomoć u pogledu obdržanja franjevačkog propovjednika fra Silvestra. ${ }^{81} \mathrm{U}$ isto vrijeme, tražio je i da se obnovi dozvola za 80 godina starog fratra Marca Pasqualija, pripadnika jednog od najznačajnijih gradskih patricijskih rodova, da živi u samostanu »ubogih Klara« u gradu, ${ }^{82}$ da bi ispovijedao redovnice. ${ }^{83}$ Franjevačke vlasti su se obratile Marcu Pasqualiju 1561. godine. ${ }^{84}$

Klauzurom $^{85}$ se nisu samo štitile žene (time što bi se izbjegavala iskušenja viđenjem), već i kler. Usto su mnoge žene stupale u monaški život protiv svoje volje ${ }^{86}$ te stoga nisu bile prikladne za religioznu vokaciju. Vizuelno se tako uskraćivalo u oba smjera ${ }^{87}$ Činjenje žene nevidljivom, »grob « konventa, ${ }^{88}$ bio je forma zaštite za celibat klera. ${ }^{89}$

Temple University; Arizona State University; University of Southern California. Center for Multiethnic and Transnational Studies; Magyar Tudományos Akadémia. Szociológiai Kutató Intézet, Brill Academic Publishers, 1993-1996, str. 158.

79 C. BRUZELIUS, »Nuns in Space«, str. 56.

${ }^{80}$ Z. JANEKOVIĆ RÖMER, »Nobel Women in Fifteenth-Century Ragusa«, str. 157.

81 Tridentski koncil je priveden kraju 4. decembra 1563. Bruni je napisao Borromeu: »uvijek sam činio veliki napor da ovaj siromašni narod održim... u katoličkoj vjeri..., iako je ova siromašna pokrajina ugnjetavana šizmaticima i muslimanima« (»sempre mi son forciato conseruar questi pouer popoli... nela fede catholica... tutto cio che questa pouer prouincia sia oppressa da scismatici et mahometani $\ll$ ). Noel MALCOLM, Agents of Empire. Knights, Corsairs, Jesuits and Spies in the Sixteenth-Century Mediterranean World, London, 2015, [Biblioteca Ambrosiana, Milano (dalje: BAM), MSS F 94 inf., fol. 214r], str. 71, 73-74, 460.

82 Sv. Klara je rođena 1194. godine u Assisiju, u plemićkoj porodici Faverone. Na Cvjetnu nedjelju 1212. godine bježi od kuće i biva primljena u franjevačko bratstvo. Sv. Franjo je odveo u ženski benediktinski samostan sv. Pavla u Assisiju, a potom se premješta u boravište pokornika sv. Anđela u Ponzi, gdje su živjele mulieres religiosae i brinule se za bolesne i siromašne. Dolaskom Klarine sestre Katarine (redovničko ime Janja), smještaju se u samostan sv. Damjana. Klara je u sv. Damjanu praktikovala potpuni post tri dana u nedjelji. Insistirala je na siromaštvu zajednice, živeći od milostinje i darova koje su za to zaduženi fratri za njih skupljali. U svojem Pravilu, čiju je potvrdu dobila tek dva dana prije smrti, obećala je poslušnost papi i njegovim nasljednicima, ali i sv. Franju. Klara je umrla 11. avgusta 1253. u samostanu sv. Damjana, u kojem je provela više od 40 godina života. Kako bi obezbijedile odvojenost »od svijeta«, radi samoće i kontemplacije, ove redovnice su uspostavile strogu klauzuru zbog čega su nazvane »rekluze« ili »zatvorene redovnice«. Gradski eremitizam omogućio im je potpuno siromaštvo u kojem im je bio dovoljan ručni rad unutar samostana $i$ prošnja milostinje. Generalni ministar Reda manje braće vrši ulogu njihova duhovnog voditelja. Marinko PEJIĆ, »Klara Asiška: Siromaštvo i pokora kao egzistencija«; s. M. Tarzicija ČIČMAK, »Povijest reda sv. Klare: Aktualnost Klare Asiške«, Klara i klarise, Svjetlo riječi, br. 340-341, Sarajevo 2011., str. 2-6, 8, 9.

83 »to live in the nunnery of Poor Clares in the city«k, N. MALCOLM, Agents of Empire, str. 73.

${ }^{84}$ BAM, MSS F 94 inf., fol. 215r. Ibid., str. 460, 532.

${ }^{85}$ Franjevke samostana sv. Klare u Kopru dijelile su se na horne sestre (sa svečanim zavjetom) i konverse (sestre laikinje bez zavjeta). Z. BONIN, »Koprski samostan svete Klare«, str. 137.

${ }^{86}$ Očevi nisu morali pitati maloljetne kćeri za saglasnost za odlazak u samostan. Z. JANEKOVIĆ RÖMER, »Nobel Women in Fifteenth-Century Ragusa«, str. 156.

${ }^{87}$ C. BRUZELIUS, »Nuns in Space«, str. 72-73.

${ }^{88}$ Nekad su udovice željele da provedu posljednje godine života unutar zidova samostana da bi se pripremile za hrišćansku smrt. S druge strane, redovništvo je moglo biti utočište u bijegu od neželjenog braka. Z. JANEKOVIĆ RÖMER, »Nobel Women in Fifteenth-Century Ragusa«, str. 159.

${ }^{89}$ U tradiciji koja seže do Origena i Tertulijana viđenje je poistovjećivano s gubitkom integritatis; kako želja može biti izazvana pogledom, viđena djevica više nije djevica. C. BRUZELIUS, »Nuns in Space«, str. 72, 73. 
Klarise inače dolaze u susjedni Kotor oko 1364. godine. Sredinom 16. vijeka »samostan je bio kažnjen zabranom primanja podmlatka, vjerovatno zbog neke javne sablazni, i tako se ugasio ${ }^{90}$. Dva su samostana sv. Klare postojala u Dubrovniku: ${ }^{91}$ jedan u 13., a drugi u 15. vijeku; drugi je imao sirotište za napuštenu djecu, jednu od prvih takvih institucija u svijetu, koja se održala do 1806 . godine, kada ga je ukinuo Napoleon..$^{92}$

\section{Pravni poslovi jedne dubrovačke dumne iz Bara}

U Dubrovniku je početkom 15. vijeka, kada je imao oko pet do šest tisuća stanovnika, bilo osam ženskih samostana. Međutim, istaknuto je da je bilo zabranjeno primati u njih strankinje. ${ }^{93}$ Redovnica Stanula Mortichiul iz Bara u jedan stari dubrovački je samostan možda stupila temeljem dvojnog građanstva, a svakako je dugi niz godina zadržala veze sa svojim posjedima u Baru i tamošnjim građanima, odnosno rodbinom. Dana 24. jula 1401. godine sestra Stana, kćerka pok. Luke Mortichiul iz Bara, dumna u (benediktinskom) ${ }^{94}$ manastjeru sv. Šimuna, sa saglasnošću i voljom opatice i monahinja rečenog manastira, utvrđujući u zakonitosti svojeg strica (!) Matea Secondinija iz Bara, postavila ga je i odredila na svaki pravni i formalni način kako je najbolje mogla, odsutnog kao prisutnog, za istinitog i legitimnog prokuratora, aktora, faktora, upravitelja poslovima i posebnog glasnika, posebno i izričito u gradu Baru i njegovu distriktu, da zamoli i zatraži, da preuzme i primi ono što bi ona sama imala, primila, ili u budućnosti dobila od bilo koje osobe na bilo koji način i to po osnovu nasljeđa svojeg oca, odnosno majke, odnosno temeljem bilo kakvog zavještanja koje joj je ostavljeno testamentima rečenih oca i majke, kao i legata svih drugih, te iz bilo kojeg drugog razloga. Navedenim je posebnim punomoćjem sastavljenim u Dubrovniku prokurator između ostalog mogao primiti pokretna i nepokretna dobra, prava koja joj pripadaju, odnosno preduzimati radnje koje se odnose na njihovu potražnju, očuvanje, čuvanje, upravljanje i davanje u zakup, a koje bi cijenio cjelishodnim. A ako bi se trebalo gore pomenutim poslom ili zbog bilo čega kazanog pojaviti pred bilo kakvim crkvenim kao i svjetovnim sudištem, u tom će slučaju opunomoćenik djelovati, štititi livel (ugovor o zakupu kojim se za ustupljenu zemlju dobija godišnja zakupnina u novcu, ili

${ }_{90}$ M. Tarzicija ČIČMAK, »Povijest reda sv. Klare«, str. 10.

${ }^{91} \mathrm{O}$ ženskom redovništvu u Dubrovniku cfr. et: Minela FULURIJA, »Utemeljenje ženskoga samostana Sv. Katarine Sijenske u Dubrovniku«, Povijesni prilozi, god. 32, br. 45, Zagreb, 2013., str. 115-134.

92 U Split klarise dolaze oko 1308. godine, gdje je samostan bio otvoren samo za pučanke. Klarise su došle u Šibenik 1391; sto godina kasnije prelaze na Pravilo sv. Benedikta. M. Tarzicija ČIČMAK, »Povijest reda sv. Klare «, str. 10.

93 Z. JANEKOVIĆ RÖMER, »Nobel Women in Fifteenth-Century Ragusa«, str. 156.

${ }^{94}$ U Dubrovniku je, po Nikoli Ragnini, relikvija Isusove Pelenice najprije čuvana nekoliko godina u crkvi sv. Šimuna podno Kaštela. »Godine 1669. bila je ishođena redukcija samostana i u samostan Sv. Marije od Kaštela bile su smještene benediktinke iz više samostana (iz Sv. Tome, Sv. Šimuna, Sv. Andrije i Sv. Marka).« Annales Ragusini Anonymi, item Nicolai de Ragnina, (digessit Speratus NODILO), Scriptores, vol. I, Monumenta spectantia historiam Slavorum meridionalium, vol. 14, Academia scientiarum et artium Slavorum meridionalium (ed.), Zagrabiae, 1883., str. 198-199; Nella LONZA, Kazalište vlasti, Ceremonijal i državni blagdani Dubrovačke Republike u 17. i 18. stoljeću, Zagreb - Dubrovnik, 2009., str. 247, 249-250, 408. Od legata Baranke Jeluše Sasinović od deset dukata namijenjenog crkvi sv. Šimuna u Dubrovniku imala se načiniti ikona za kapelu »de Sancta Maria Madalena«. Državni arhiv u Dubrovniku [dalje: DADU], Testamenta notariae [dalje: TN], sv. 12, fol. 14v (8. februar 1426.). 
dio prihoda; kolonat), ulagati, primati i osporavati žalbe i tužbe, te pred drugim strankama govoriti istinu u ime i po duši davateljke punomoćja, slušati, protestovati, izvršavati, apelovati, kao i sve drugo opšte i pojedinačno činiti što sporna stvar bude zahtijevala i kako vidi i procijeni da bi bilo korisno, neophodno i oportuno. Posebno su punomoćje, ispravu koja će proizvoditi konkretno i neposredno pravno dejstvo po davateljku ovlašćenja (kao da je lično prisutna), opravosnažili dubrovački sudija g. Marin de Bodazia i g. Alberto Bono iz Belluna, notar i kancelar u Dubrovniku, u svojstvu svjedoka. ${ }^{95}$

Dana 6. oktobra 1417., sestra Stanula, kćerka pok. Luke Mortichiuoli iz Bara, tada monahinja u klauzuri samostana sv. Šimuna u Dubrovniku, s voljom i saglasnošću gđe Katarine, opatice navedenog monastjera, na svaki je pravni i formalni način, kako je najbolje mogla, uprkos proteku vremena za koje je Matej Saguntino(v?) ${ }^{96}$ (Secondino; Secondini Mortichiul?) iz Bara, kojem je preko fra (?) Nikole, brata rečene Stanule, dat u zakup neki vinograd i izvjesni posjedi, odnosno tereni, o kojem je zakupu Stanula dala da se sačini javna isprava koja se nalazi kod istog Mateja, a on zakup vinograda i terena nije platio, zbog čega je toga prava po ugovoru o zakupu mogao biti lišen - odsutnog zakupca Mateja preko notara potvrdila i opravosnažila shodno običaju, uslovima i uglavcima sadržanim u odnosnoj ispravi o zakupu, u želji i na način da isti Matej od sada i ubuduće ima, drži i posjeduje rečeni vinograd i ostalo što navedeni instrument sadrži bez protivljenja, uznemiravanja i smetnje bilo koje osobe. Ispravu su potvrdili g. Nikola Petrov de Poza, sudija, i Rusko magistra Kristofora, svjedok. ${ }^{97}$

Sestra Stanula, kćerka pok. Luke Mortichiuoli iz Bara, tada redovnica samostana sv. Šimuna u Dubrovniku, 25. oktobra 1417. je na svaki način - stavljajući van snage i opozivajući sva prethodno izdata punomoćja - učinila i konstituisala Nika, sina Mateja de Saguntino, za svojeg prokuratora, aktora, faktora i posebnog glasnika, navlastito u pogledu posjeda koje je držala po osnovu nasljeđa u Baru i njegovu distriktu. Odsutnom kao prisutnom, Niku de Saguntinu je povjerila da u njeno ime može tu ili drugu imovinu dati u zakup, uzeti iz zakupa, zahtijevati, potraživati i primiti plodove i prihode od nje, njoj ih poslati te ugovarati da se ista dobro i valjano obrađuje. Plodove koje primi u ime davateljke punomoćja prokurator joj je trebao uručiti provođenjem shodnih formalnosti. A ako posao bude zahtijevao pojavljivanje pred sudom, opunomoćenik je trebao postupati prema okolnostima i prosuđivanju, osporavati, tražiti, primati, braniti i ostvarivati njena prava, posredstvom drugih advokata i prokuratora, čineći sve opšte i posebno što je potrebno i neophodno da se parnica i sporna stvar dolično i djelotvorno okončaju. Takođe se mogao zaklinjati u njenu dušu. Ispravu, koja je izdata, opravosnažili su sudija g. Nikola P. de

\footnotetext{
${ }^{95}$ DADU, Diversa cancellarie, sv. 33, fol. 208r. Snimke citiranih dokumenata iz DADU ustupila mi je prof. dr. sc. Nella Lonza, na čemu joj, kao i na kolaciji priloženih isprava (Diversa cancellarie i Diversa notariae), te na dragocjenim sugestijama i napomenama, najljepše zahvaljujem.

${ }^{96}$ Ukoliko je riječ o patronimu, to je ime izvedeno iz rimskog kognomena Secundinus, koji potiče od imena Secundus (Drugorođeni / koji »pripada Secondu« / Drugom / »Secondov potomak«) - ako ovdje nije samo deminutiv. Više je svetaca s tim imenom: sv. Kasio i Sekundin, biskupi i mučenici u Kampaniji; sv. Donat, Sekundin, Romul i prijatelji, mučenici u Concordiji (u blizini Akvileje, na granici s Furlanijom), u vrijeme Dioklecijana. Ime Sekundo javlja se u vlasteoskom krugu u Dubrovniku u prvoj polovini 15. stoljeća. Nenad VEKARIĆ, Vlastela grada Dubrovnika, Svezak 9: Osobna imena, Zagreb - Dubrovnik, 2018., str. 89.

${ }^{97}$ DADU, Diversa notariae, sv. 12, fol. 190r.
} 
Poza i svjedok Rusko magistra Kristofora, a sa voljom i saglasnošću gđe Katarine, opatice navedenog samostana. ${ }^{98}$

\section{Svetište sv. Fabijana: crkva samostanskog kompleksa?}

Pored samostanske crkve sv. Andrije u Baru (sada s titularkom sv. Venerandom) nalaze se ostaci starije crkve, ne mlađe od 13. vijeka, koja je po svojim dimenzijama bila mnogo veća nego što je danas, a koja se svojim jugoistočnim krajem srušila prema kanjonu rječice Bunar. ${ }^{99}$ Ostaci zidova građevine označene brojem 47 bili su porušeni (obrušeni) prije nego što je nad njenim sjeverozapadnim uglom podignut istočni zid crkve sv. Andrije. ${ }^{100}$

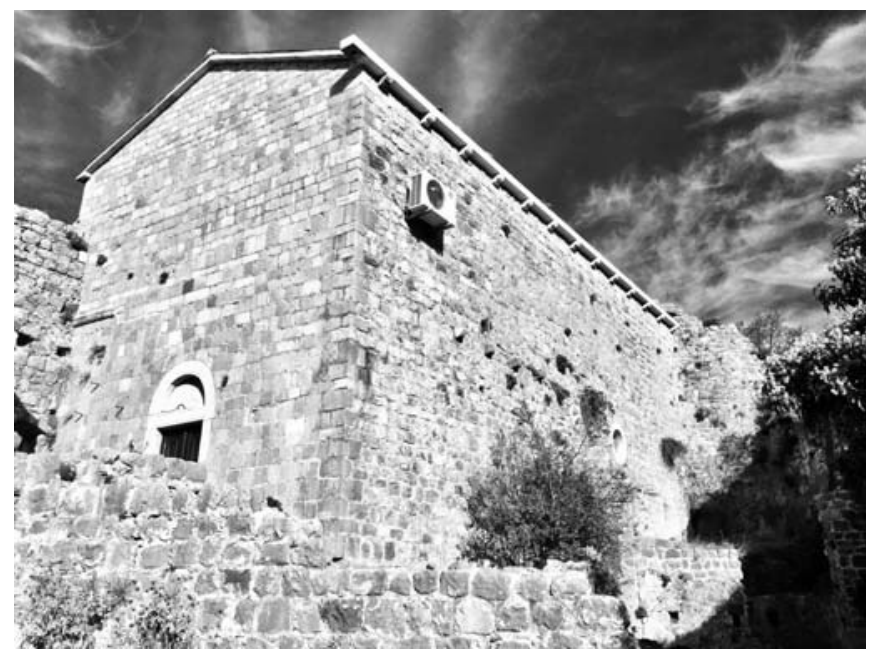

Sl. 14. Pogled na stražnji dio crkve sv. Andrije (i prostor objekta br. 47 - crkve iz 13. vijeka?) (photo: S. Marković, 2017.)

Njen sjeverni zid ide do blizu vanjskog gradskog zida, da bi kasnije bio produžen, vjerovatno do zidina. ${ }^{101}$ Prema načinu zidanja (grubi kvaderi nejednake visine) pripada zrelom srednjovjekovlju. ${ }^{102}$ Starija crkva bila je funkcionalno povezana sa susjednim zgradama $i$ prije gradnje novije crkve (sv. Andrije). Pozicionirana je u skladu sa objektom br. 43, koji je, pretpostavlja se, bio kasnosrednjovjekovni odbrambeni toranj na gradskim zidinama, možda dio samostanskog ili kasnijeg stambenog kompleksa, iz kojeg se mogla kontrolisati

\footnotetext{
98 DADU, Diversa notariae, sv. 12, fol. 191v.

99 Cfr.: Đ. BOŠKOVIĆ, Stari Bar, str. 35-41. Idem, »Izveštaj i kratke beleške sa putovanja«, Starinar, treća serija, knjiga šesta, Beograd, 1931., str. 148; idem, »Rad na proučavanju i tehničkoj zaštiti Staroga Bara«, Zbornik zaštite spomenika kulture, knjiga IV-V, 1953-1954, Beograd, 1955., str. 439-440; M. ZAGARČANIN, Stari grad Bar, str. 42.

${ }^{100}$ Đ. BOŠKOVIĆ, Stari Bar, str. 35, 38.

${ }^{101}$ Ibid., str. 35.

${ }^{102}$ Ibid.
} 
uvala potoka Bunar. ${ }^{103}$ Prostor objekta br. 47, u kojem je prepoznata apsida starije crkve, kasnije je adaptiran za poljoprivrednu proizvodnju i u njemu smještena uljna presa. ${ }^{104} \mathrm{Na}$ bočnom zidu crkve sv. Andrije nalaze se dva reda konzola, koje indiciraju postojanje međuspratnih konstrukcija, visokih spratova. ${ }^{105}$

Ne bi se moglo isključiti da je ta crkva bila posvećena kultu sv. Fabijana. U testamentu Baranina Ivana Ferroa od 18. avgusta 1556. godine pomenut je raniji legat jedne peče kariseja, koji je bio ostavljen samostanu monahinja sv. Fabijana: »una pezza di carisea lasciato al monasterio di monache s. Fabiano in Antivari « ${ }^{106}$. Taj svetac se, međutim, kao mučenik iz prvih hrišćanskih vremena, slavio kao zaštitnik od kuge zajedno sa sv. Sebastijanom, i njihova su imena ušla u litanije Svih svetih ${ }^{107}$ Zaštitnik je od kuge i kužnih bolesti, kovača, livaca i lončara.

\section{Vodosnabdijevanje samostana: ključ utvrđivanja njegova kulta}

$\mathrm{Na}$ osnovu arheoloških istraživanja evidentirano je više cisterni u Starom gradu Baru: u Citadeli, u objektu u blizini današnje ljetne teatarske scene (2), u kući br. 143, u objektu br. 136 (prepoznatljivom po arkadama), u Hospicijumu, u objektu br. 37 (Loggia), u stambenoj zgradi u blizini crkve danas posvećene sv. Katarini. Pored ovih, u objektu br. 51 nalaze se dvije cisterne, a u dvorištu (objektu) br. 44 jedna. Inače je, prema istraživanjima Đ. Boškovića, u gradu i na njegovim fortifikacijama evidentirano četrnaest crkava, kapela i crkvišta; uzima se i da ih je identifikovano oko šesnaest, dok nadbiskup Marin Bizzi 1610. kaže osamnaest crkava. ${ }^{108}$

Pozivajući se na vrijeme (»che al presente vive«) barskog nabiskupa Andrije Zmajevića, 1688. godine (»Il presente Arcivescovo è Andrea Zmaievich da Perasto, di anni 64.«), V. Coronelli 1703. objavljuje da su u kući nadbiskupa dva puča, ali da su ti bunari puni nečistoće (»Vi sono altri 2. pozzi in casa dell'Arcivescovo; ma ripieni d'immondezze «). ${ }^{109}$ Međutim, Coronelli prije toga ističe da u cijelom gradu Baru postoji samo jedan puč, s kišnicom, smješten u kući Mehmeda Čelebije Omer Beriša, koja je prije bila konvent redovnica sv. Andrije: »Ha un solo pozzo nella Città, situato in Casa di Mecmeth Colepia Omer Berisch, che prima era Convento delle Monache di S. Andrea, con acqua piovana. «110

\footnotetext{
${ }^{103}$ F. BAUDO - D. CALAON - E. D’AMICO, »From monastery (?) to Ottoman house«, str. 84-85, 93, 95.

${ }^{104}$ Ibid., str. 83.

${ }^{105}$ Đ. BOŠKKOVIĆ, Stari Bar, str. 35.

${ }^{106}$ S. MARKOVIĆ, Stanovništvo srednjovjekovnog Bara, str. 806.

${ }^{107}$ Fabijan je (iz okoline) došao u Rim slučajno; kada mu je na glavu sletjela golubica 236. godine, izabran je za papu. Za njegova četrnaestogodišnjeg pontifikata nije bilo progona hrišćana. Tradicija mu pripisuje podjelu Rima na sedam područja, a jedan od pokrajinskih đakona bio je sv. Lovro. Umro je 250. godine u Rimu, kao mučenik, s početkom Decijevih progona.

${ }^{108} \gg$ the town in characterized by several Christian religious buildings (about 16 churches, chapels and monasteries have been identified at present) (...)«. S. GELICHI, »Introduction«, str. 10. »il resto coi beni di altre chiese, ch' erano dentro della città al numero di 18 e fuori di 48«, F. RAČKI, »Izvještaj barskoga nadbiskupa Marina Bizzia«, str. 65.

${ }^{109}$ Fra Vincenzo CORONELLI, Biblioteca Universale Sacro-Profana, Antico-Moderna, Tomo terzo. Am-Ao. In Venezia, M. D. CCIII. A' Spese di Antonio Taviani, 1237-1238.

${ }^{110}$ V. CORONELLI, Biblioteca Universale Sacro-Profana, Antico-Moderna, 1237-1238.
} 
Ukoliko bi se pošlo tragom pomenutoga Čelebije u vremenu barskog nadbiskupa Andrije Zmajevića, treba istaći da u izvještaju o nadbiskupskoj vizitaciji Baru od 23. septembra 1671. Zmajević navodi jednog Čelebiju, ali konkretnije drugačije određenog: »došao je na konju Ahmet Čelebija Mustafagich, jedan od glavnih Turaka u gradu, sa povorkom od dvadeset dvojice ostalih sadrugova, dovodeći konje za mene i moje popove i klerike, ispred kojih, u prelatskom habitu, sa ogrtačem i krstom pred grudima bijah uveden u grad, gdje me na vratima dočekaše stariji ljudi te me otpratiše do kuće koja mi je bila pripremljena, $u$ blizini nadbiskupske palate, u kojoj sam se smjestio ${ }^{111}$. Znatno ranije, u Baru se bilježi još jedan Čelebija: »Cussain Celebi figliolo de Aliaga«, naveden je 24. januara 1594., iza barskog emina Frane Pekova, u testamentu Baranina Mattea, sina Luke i Ore Rugia (»Mattheo di Luca Rugia«), sastavljenom u Dubrovniku. ${ }^{112}$ Iako se ni ovdje ne uočava neposredna povezanost sa odnosnom nekretninom, vjerovatno je pomenuti Husein bio gradski moćnik. Od (nekad Ulcinjanina) Cristifora Bruttija, koji je bio u Kopru, mletačke vlasti su sredinom marta 1588. godine tražile »da ide niz obalu u Kotor kako bi pomogao da se zaustave gusarski postupci protiv venecijanskih brodara, koje su počinili »mnogi osmanski podanici«, a podržavao ih je istaknuti barski spahija, »Cassain««"13 (Husein). Mogao bi to biti isti Assan Celebia, koji je 1610. godine dočekao nabsikupa Marina Bizzija prilikom njegove posjete Baru, kada mu je za stanovanje ustupio svoju kuću. ${ }^{114}$

Samostanski sklop svakako nije bio mali. Četvorougaona jednostavna prostorija br. 43 vezana za gradski zid u gornjem dijelu svojeg sjevernog zida ima vrata koja je vezuju sa susjednim dvorištem br. 44, a na južnoj strani druga, vidljiva iz prostorije označene brojem $42 .{ }^{115} \mathrm{Na}$ osnovu konzola zaključuje se da je zgrada imala najmanje tri etaže. Po dimenzijama unutrašnjeg prostora objekat koji je služio odbrani ${ }^{116}$ ovog dijela grada svakako »prelazi veličinu obične kule, a i zidovi su mu za kulu relativno tanki. Nije isključeno da je bio vezan i za manastirski kompleks $48 \ll .{ }^{117}$ Toranj je možda bio dio samostanskog ili kasnijeg stambenog kompleksa jer je sa gornjeg sprata rezervoara za vodu otvor vodio

\footnotetext{
${ }^{111}$ S. MARKOVIĆ, »Prvi Izvještaj Andrije Zmajevića o Barskoj nadbiskupiji Sv. kongregaciji«, str. 211.

${ }^{112}$ DADU, TN, sv. 49, ff. 154v-155v.; Savo MARKOVIĆ, »Jadranske trajektorije De Ruggiis«, 8. Istarski povijesni biennale, Artisani et mercatores: o obrtnicima i trgovcima na jadranskom prostoru, Zbornik radova s međunarodnog znanstvenog skupa održanog u Poreču od 11. do 13. svibnja 2017., sv. 8, Marija MOGOROVIĆ CRLJENKO - Elena ULJANČIĆ (ur.), Poreč, 2019., str. 137.

${ }^{113}$ N. MALCOLM, Agents of Empire, str. 371-372. Na str. 513: [16] »ASVen, Dispacci, Costantinopoli, filza 26, fos. 372r ('molti sudditi Turcheschi', Cassain, vessel seized), 402r (petitions), 402v, 403v (meeting in Kotor)《.

${ }^{114} \gg$ Quella notte havend' io mandato l' aviso del mio arivo ai Christiani della città venero la seguente matina molti di loro dei primati et anco molti Turchi di conto à condurmi, tra quali (...) Assan Celebia, e già mi havea concessa la sua casa per habitarvi«, F. RAČKI, »Izvještaj barskoga nadbiskupa Marina Bizzia«, str. 65.

${ }^{115}$ Objekat 42 je možda bio sporedni ulaz u grad; na sjevernom zidu, prilično visoko, nalaze se vrata (do kojih se stizalo drvenim, ili kasnije porušenim stepeništem) koja vode u susjednu prostoriju 43. Đ. BOŠKOVIĆ, Stari Bar, str. 34.

${ }^{116}$ Tokom 15. stoljeća dolazi do proširenja samostana benediktinki na Rabu, kada je i južni gradski zid uz zapadno krilo svetilišta bio ojačan kvadratičnom kulom s puškarnicama. Srednjovjekovna kula markirala je zapadni kraj samostana. Katarina HORVAT-LEVAJ, »Samostan benediktinki sv. Andrije na Rabu. Prilog povijesti gradnje«, Prostor, Zagreb, br. 27 [2019], 2 [58], str. 199, 205.

${ }^{117}$ Đ. BOŠKOVIĆ, Stari Bar, str. 34-35.
} 
na prvi sprat tornja. ${ }^{118}$ Prostrani vodeni tank unutar kompozita distingvira ovaj građevinski sklop od ostalih stambenih jedinica u gradu. ${ }^{119}$

Dvorište objekta 43 označeno br. 44, bilo je s njim povezano vratima u visini sprata, »a možda su zajedno bili u sklopu manastirskog kompleksa crkve $48 «^{120}$. Istočni zid te prostorije dio je gradskih zidina, za koji su vezani ostaci pločnika. ${ }^{121} \gg$ Cisterna, izgrađena u samom dvorištu, u kojoj još uvek ima vode, dugačka je oko 7-7,50 m, visoka oko 5,00 m, sa svodom raspona oko $5,00 \mathrm{~m}$, rađenim od dosta uskih ploča $6-12 \mathrm{~cm}$ širine i nejednake dužine, $30-60 \mathrm{~cm}$. Malterisana je čisto, malterom u kome ima izgleda gline ili neke druge pečene zemlje, cementne vrste. Pri malterisanju su uglovi zaobljeni. Na polovini visine svoda, sa njegove severne strane, bliže zapadnoj, ugrađen je slivnik koji je vodu propuštao kroz perforiranu kamenu ploču. Oko dvadeset malih kružnih otvora, prečnika oko $2 \mathrm{~cm}$, raspoređeni su na međusobnim horizontalnim rastojanjima od oko $2 \mathrm{~cm}$ i vertikalnim od oko $4 \mathrm{~cm}$. Ispod ploče, koja je postavljena vertikalno, postoje i dve zakošene ćeramide preko kojih se slivala voda naniže. Veličina svodara iznosi $15-30 \mathrm{~cm}$, a debljina svoda, zajedno sa pokrivačem iznad njega oko $60 \mathrm{~cm}$. Spojnice su izvedene malterom od kreča i tucane sige. $\ll^{122}$

$\mathrm{Na}$ prostoru označenom br. $45,{ }^{123}$ arheološki temeljno istraženom 2005. godine, konstatovana su dva kanalizaciona sistema drenaže. Jedan je moguće korišten za prikupljanje kišnice i vjerovatno vodi u veliki rezervoar za vodu objekta br. $44 .{ }^{124}$ Drugi je sasvim plitak i moguće da je bio korišten za skupljanje otpadnih voda blizu male kadice obložene kamenom i ožbukane vodonepropusnim ružičastim malterom, korištene možda kao posuda za pojenje stoke ili drugih domaćih životinja. ${ }^{125}$

Objekat 46, zgrada sa prizemljem i spratom iz zrelog ili kasnog srednjeg vijeka, »ssvakako stambenog karaktera, a verovatno vezana za kompleks manastirskih zgrada postavljenih uz crkvu sv. Venerande«, starija je od crkve, »jer se zapadni, bočni zid ove poslednje naslanja na njenu severnu fasadu ${ }^{126}$. »U najbolje očuvanoj prostoriji, na severnom zidu, ispod kasnije usečenog kamina, nalazi se sa leve strane jedna konzolica - fragment doprozornika ili dovratnika, u obliku krupne tordirane trake odnosno tordirane ugaone kolonete. Moguće da je ovaj fragment uzet sa nekog starijeg objekta - sa crkve sv. Đorđa ili sv. Nikole. $\ll^{127}$

Zgrada 47, iz zrelog srednjeg vijeka, koja se svojim sjeverozapadnim uglom (starijim, obrušenim zidom) podvlači pod zid crkve sv. Andrije, sjevernim zidom ide do vanjskih

\footnotetext{
${ }^{118}$ F. BAUDO - D. CALAON - E. D’AMICO, »From monastery (?) to Ottoman house «, str. 95.

119 »inside the compound «, Ibid., str. 96.

${ }^{120}$ Đ. BOŠKKOVIĆ, Stari Bar, str. 35.

${ }^{121}$ Ibid.

${ }^{122}$ Ibid.

${ }^{123}$ Objekat 45, tj. njegov prostor, Đ. Bošković je dovodio u vezu (»utisak«) sa ćelijama »u kakvom manastirskom kompleksu, vezanom za crkvu sv. Venerande«; »Ovo naročito zato što su prostorije male i sasvim slabo osvetljene. « Ipak, nije isključio da je riječ o sporednim prostorijama neke veće zgrade, s južne strane. Ibid.

${ }^{124}$ F. BAUDO - D. CALAON - E. D’AMICO, »From monastery (?) to Ottoman house«, str. 93.

${ }^{125}$ Ibid.

${ }^{126} Đ$. BOŠKOVIĆ, Stari Bar, str. 35.

${ }^{127}$ Ibid.
} 
gradskih zidina, kojem se priključuje. Đ. Bošković je pretpostavljao da se u ovoj zgradi stanovalo ili da su u njoj bili smješteni vojnici. ${ }^{128}$

Coronellijevo, odnosno Zmajevićevo svjedočanstvo, međutim, već nekoliko godina kasnije nije doslovno potvrđeno od barskog prelata rodom iz susjednog Spiča. Kako je već citirano, nadbiskup M. Giorga 1697. godine navodi da već tada nije bilo poznato kojeg su reda i pravila redovnice bile, »ni kojemu je svecu bila posvećena njihova crkva, koja je sada pretočena (!) ${ }^{129}$ u kafanu (točionicu), a samostan u stan nevjernika ${ }^{130}$.

Kako je konvent postao privatno prebivalište, postavlja se pitanje što se skladištilo, tj. podrazumijevalo pod konobom (kafanom, odnosno točionicom), koja se nalazila u crkvi? U literaturi je iznijeto stanovište da su podužna pravougaona duboka spremišta za žito ili ulje u crkvi napravljena vjerovatno u doba mletačke vlasti. ${ }^{131} \gg \mathrm{U}$ podu crkve, paralelno sa bočnim zidovima, ugrađene su dve 'sarandže', dve duboke podužne jame, ${ }^{132}$ - dva silosa, - čiji su zidovi u jezgru rađeni od lomljenog kamena, dok im je unutarnje lice od dobro otesanog krečnjaka. Obrađene ploče, sem nekoliko njih, obrađene su i odnete. Malter koji je upotrebljen za zidanje veoma je čvrst i rađen od kreča i tucane opeke. Oba silosa bila su, poprečno postavljenim pločama uglavljenim u bočne zidove, podeljena - zapadni na četiri, a istočni verovatno na pet odeljenja. « $^{133}$

»Po kazivanju meštana ova dva silosa - cisterne urađena su pre 120 godina. Drugi navode da ih je konstruisao Đuro Nikezić, sin Marka Božova, 'odmah po oslobođenju Bara od Turaka', jer se zgrada za vreme Turaka nije upotrebljavala u religiozne svrhe. Svi se slažu u tome da se u ovim dubokim, precizno ozidanim cisternama držalo ulje, i to direktno sipano, kao u neku vrstu basena. Ovo ne izgleda mnogo verovatno, jer se ulje moglo užegnuti, a ne vidi se ni način na koji je vađeno. Daleko je međutim verovatnija pretpostavka dr Cvita Fiskovića, da je ovde moglo da bude čuvano žito. Po načinu zidanja i po obradi ploča od kamena može se isto tako zaključiti da su silosi daleko stariji od vremena u koje ih stavljaju neupućeni meštani i da pripadaju verovatno razdoblju pre zauzimanja Bara od strane Turaka, to jest da su ugrađeni još u doba mletačke vlasti u Baru. $\ll^{134}$

\footnotetext{
${ }^{128}$ Ibid.

${ }^{129}$ Valde »pretvorena«, prim. S. M.

${ }^{130}$ Š. RASTODER, »Izvještaj Marka Giorga o Barskoj nadbiskupijI «, str. 159.

${ }^{131}$ Đ. BOŠKOVIĆ, Stari Bar, str. 39. »Room 48, the church of St. Veneranda, was used as a deposit for grain as testified by the construction of two large rectangular vats under the floor. (...) rooms 46 , which were probably used as storage areas due to lack of openings towards the exterior.« F. BAUDO - D. CALAON - E. D'AMICO, »From monastery (?)«, str. 93.

${ }^{132}$ Ta su »dva duboka kasnije ugrađena rezervoara za ulje ili žito« potpuno raščišćeni 1954. godine, ali se 1. septembra 1955., poslije jake kiše, srušio bočni zid rezervoara. Đ. BOŠKOVIĆ, »Istraživački, arheološki i konzervatorski radovi u Starom Baru 1951-1955«, str. 201, 204.

${ }^{133}$ Đ. Bošković na t. XXXIV donosi sliku južnog dijela zapadnog rezervoara, a na sl. 49 (obj. 48) »detalj silosa za žito«. Đ. BOŠKOVIĆ, Stari Bar, str. 38, 40.

${ }^{134}$ Ibid., str. 39-40.
} 


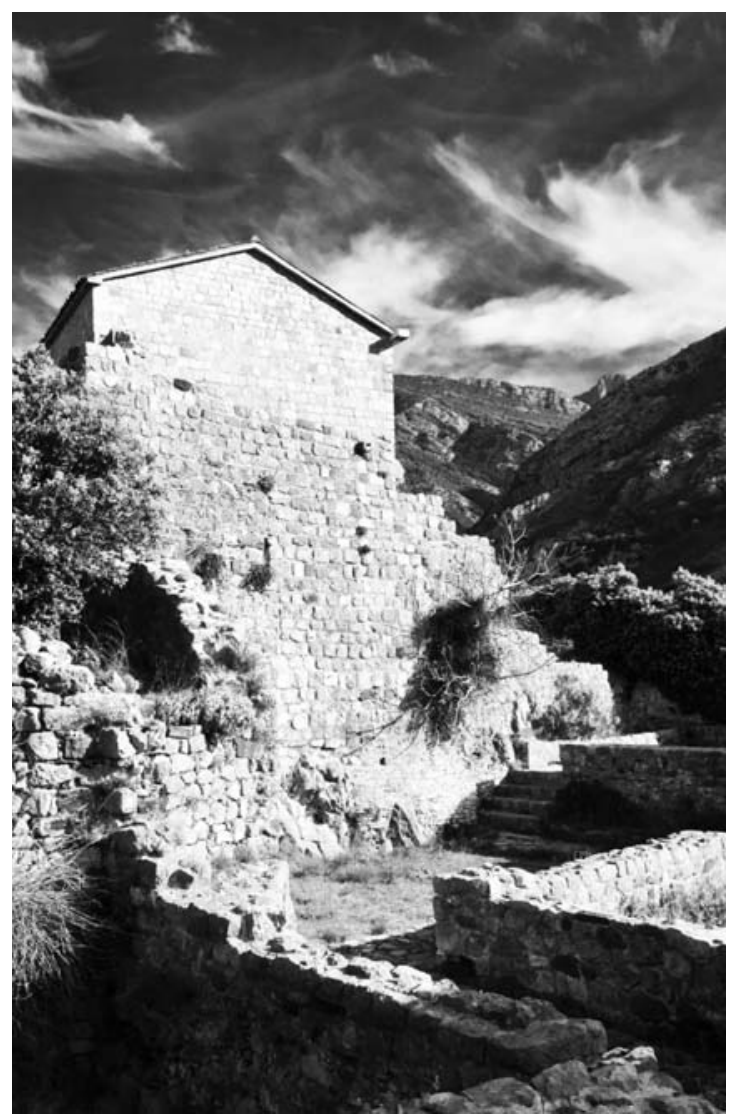

SI. 15. Južna strana samostanskog kompleksa sv. Andrije, prema objektima 43-46 (photo: S. Marković, 2017.)

Objekat 49 (imao je jedan sprat), smješten između crkve, objekata 47 i 50 te gradskog zida, takođe se pripisuje samostanskom kompleksu. Jednim kasnijim otvorom bio je vezan za prvi sprat zgrade 50 , a drugim otvorom sa "prostorijom» između apside i obimnih zidova $u$ jugoistočnom uglu crkve. ${ }^{135}$ Objekat 50 nalazi se sjeverno od crkve, s portalom koji završava arhitravom i segmentastim lukom iznad njega. ${ }^{136}$ Istočno od objekta 50 nalazi se objekat 51, okrenut malom dvorištu u koje se ulazi iz ulice. $\mathrm{U}$ kasnom srednjem vijeku bio je dvospratan, s drvenom međuspratnom konstrukcijom. »Ispod spoljnjeg ulaznog stepeništa nalazi se vrlo mala i plitka cisterna uklesana u stenu. U pećini koja komunicira sa prizemljem postojala je još jedna, veća. ${ }^{137}$

\section{7. »Monasterio di m. Santo Andrea« u arhivskim izvorima: pitanje pripadnosti redovničkoj zajednici}

Istorijski izvori za ženske samostane rijetko su saznajno adekvatni i zbog fluidnosti ženskih redovničkih ustanova i kuća teže se mogu pratiti pojedinosti u odnosu na redove nego njihove opšte prilike. ${ }^{138}$ U nevolji su redovi jedni drugima za neko vrijeme ustupali svoje

\footnotetext{
${ }^{135}$ Ibid., str. 40.

${ }^{136} \mathrm{Na}$ tom mjestu su prvobitno postojala dva objekta, ali je do većih građevinskih intervencija došlo vjerovatno gradnjom susjedne crkve, u drugoj polovini 15. ili početkom 16. vijeka Prisutni su nalazi drugostepene plastike, profilovani podprozornicima i konzolama. Ibid., str. 40-41. Na odnosnoj je stambenoj zgradi 1954. godine izvršeno preziđivanje doprozornika na sjevernom dijelu zapadnog zida. Đ. BOŠKOVIĆ, »Istraživački, arheološki i konzervatorski radovi u Starom Baru 1951-1955«, str. 207, 208.

${ }^{137}$ Đ. BOŠKOVIĆ, Stari Bar, str. 41.

${ }^{138}$ C. BRUZELIUS, »Nuns in Space«, str. 54.
} 
kuće ili jedni druge za duže vrijeme primali ${ }^{139}$ pod svoj krov. ${ }^{140}$ Nekoliko je samostana benediktinki u cjelosti pristupilo klarisama, a takve nove klarise su uz prihvaćeno pravilo sv. Franja nastavile da i dalje vrše pravilo sv. Benedikta. ${ }^{141}$ Između 1533. i 1555. koludrice osorskog sv. Benedikta jednoglasno su prihvatile franjevački način života. Na promjenu je pristao mjesni biskup, i odobrio je papa. ${ }^{142}$ Nestankom ili odlaskom benediktinki (i benediktinaca) veliki broj njihovih zgrada crkvene ili građanske vlasti predale su sljedbenicima sv. Franja. Tako je u 16. vijeku bilo i sa benediktinskom sv. Marijom u Budvi. ${ }^{143} \mathrm{Na}$ molbu kotorske komune papa Urban V. je 1364. godine ovlastio kotorskog biskupa Dujma da poradi da se o trošku komune uredi samostan za trideset klarisa i njihovu opaticu, na mjestu nekadašnjeg samostana benediktinki. Klarise su u njemu živjele do 1575. godine, kada ih nasljeđuju franjevci opservanti, čija crkva nosi staro ime sv. Klare. ${ }^{144}$ Franjevci su naslijedili benediktinske crkve i zgrade u Istri: sv. Andrije kod Rovinja, sv. Mihovila kod Bala i sv. Grgura u Kopru. ${ }^{145}$

Nestajanjem monaha u benediktinskim ustanovama bilo je pokušaja da se to opšte umiranje zaustavi i tako produži život starim opatijama, te je crkvena vlast naređivala franjevcima da obuku crni habit, prihvate benediktinsku regulu i upravljaju opatijom koja se gasila. Papa Eugen je 1441. godine naredio franjevcu Marku iz Senja da »položi benediktinsku profesiju i primi opatsku službu u samostanu Sv. Marije na Racu blizu Bara « ${ }^{146}$. Zbog navedenih prelaza i nasljeđivanja, kod franjevaca su se čuvale benediktinske uspomene, poput oltara, knjiga i kodeksa iz propalih biblioteka. ${ }^{147}$

Iako od treće decenije 13. vijeka dolazi do opadanja broja benediktinaca, ${ }^{148}$ na kraju srednjovjekovlja dolazi do oživljavanja benediktinskih samostanskih zajednica, tako da je u ranom 16. vijeku broj monahinja desetostruko premašivao njihov broj od dva i po vijeka

\footnotetext{
${ }^{139} \mathrm{Kad}$ je ukinuta opatija sv. Jakova u Višnjici po Napoleonovoj okupaciji Dubrovačke Republike, posljednji višnjički monah našao je utočište i proživio svoje posljednje dane kod male braće u Dubrovniku. Ivan OSTOJIĆ, »Dodiri između benediktinske i franjevačke ustanove u Hrvatskoj«, Crkva u svijetu, sv. 1, br. 1, Split, 1966., str. 41.

${ }^{140}$ Izvori sadrže podatke o naizmjeničnom pružanju pomoći i drugim uslugama među sljedbenicima sv. Benedikta i sv. Franja; oba reda su ponekad zajednički karitativno djelovala: benediktinke sv. Marije u Zadru su zajedno s klarisama sv. Nikole držale hospital sv. Bernardina u istom gradu. I. OSTOJIĆ, »Dodiri između benediktinske i franjevačke ustanove«, str. 40.

${ }^{141}$ Najstariji takav slučaj zabilježen je 1260. godine, kada je nadbiskup Lovre dozvolio, s potvrdom pape Aleksandra III., da se samostan benediktinki sv. Nikole izuzme iz redovne nadbiskupove jurisdikcije i pridruži ženskoj grani obitelji sv. Franja, čime je postao prvi samostan klarisa na Balkanu. Ibid., str. 42.

${ }^{142}$ Koludrice zadarskog samostana Sv. Marije htjele su početkom 16. vijeka da pređu u strožiji franjevački red, ali im to nije dopustio papa Julije II. Ibid.

${ }^{143}$ Ibid., str. 43, 44.

${ }^{144}$ »posseduta in origine dalle Benedettine, indi dalle Clarisse, fu consegnata nel 1573 ai Minori Osservanti«, Donato FABIANICH, Memorie storico - letterarie sopra alcuni conventi della Dalmazia, Venezia, 1845., str. 25; I. OSTOJIĆ, »Dodiri između benediktinske i franjevačke ustanove«, str. 44.

${ }^{145}$ Crkva sv. Andrije na ostrvu Sera blizu Rovinja je bulom pape Nikole IV. predata franjevcima 1454. godine, a oni su je, nastojanjem sv. Ivana Kapistrana, obnovili i povećali samostan. Benediktinski priorat sv. Grgura pripao je u 15. stoljeća mletačkim klarisama, koje su ga predale svojoj redovničkoj braći franjevcima opslužiteljima, a ovi 1530. godine franjevcima trećoredcima. Taj samostan je neko vrijeme pripadao i hrvatskim glagoljašima. I. OSTOJIĆ, »Dodiri između benediktinske i franjevačke ustanove«, str. 46, 47.

${ }^{146}$ Ibid., str. 48.

${ }^{147}$ Ibid., str. 47.

${ }^{148}$ Dešavalo se da monasi napuštaju benediktinsku i prelaze na franjevačku regulu. Ibid., str. 41.
} 
ranije. ${ }^{149}$ Upoređenja radi, značajno je istaći da je u Dubrovniku krajem 14. vijeka bilo 24 klarisa i 18 benediktinki te 37 reclusa, a 1527. godine 286 redovnica (»moniales claustrales «), naspram 39 isposnica i trećoretkinja. ${ }^{150}$ Međutim, teško je prepoznati i isposnice (recluse), pobožne žene koje su živjele uz crkve, ali izvan samostanske zajednice, dok su prostorije isposničkih stanova (ćelija) uništene kasnijim pregradnjama. ${ }^{151}$ Tokom 15. i 16. vijeka reclusoria nestaju, bivajući zamijenjeni samostanskim zajednicama trećoretkinja ${ }^{152}$ ili karitativnim ustanovama. ${ }^{153}$ Iznošene pretpostavke nisu isključivale da su dominikanci držali samostanski kompleks barske crkve (s kultom pripisanim sv. Venerandi), koja »neobično liči na dominikanski ${ }^{154}$ i franjevački manastir u Dubrovniku «155. Postavlja se, međutim, prije toga, pitanje njene sličnosti (uzora) s elementima pročelja franjevačkog samostana u Baru. ${ }^{156}$

U svakom slučaju, jedna je sestra u Baru na kraju 15. vijeka stanovala kod svojeg rođaka. »Soror Dominica de Antibaro« je, dopuštenjem starješine dominikanskog reda datim u Rimu 1. jula 1492., bez prepreka mogla stanovati sa sveštenikom Paulom Vinkovićem (Bincovich), svojim rođakom. U Veneciji je 10. jula 1493. starješina dominikanskog reda istakao da sestra Dominika »tercii ordinis«, može »stare Antibari« i stanovati zajedno s »presbytero Paulo Antibariensi $\ll .{ }^{157}$ Skupština kotorskog samostana sv. Nikole je 1520. godine taj samostan darovala dominikankama trećeg reda, koje su dotle stanovale po privatnim kućama u gradu, preuzevši pri tom njihovo duhovno vodstvo. ${ }^{158}$ Možda su se (konzervativne) sljedbenice sv. Benedikta pridružile novijim regularnim strukturama, ustupajući kuće, vrtove i posjede, prihvatajući pravilo sv. Dominika u novom samostanu. ${ }^{159}$

\footnotetext{
${ }^{149}$ N. LONZA, »The houses of recluse (reclusoria)«, str. 306.

${ }^{150}$ Podaci za recluse u 14. vijeka su iz 1382., a za klarise i benediktinke iz 1397. godine. Ibid., str. $301,306$.

${ }^{151} \mathrm{Ne}$ tražeći socijalnu izolaciju, recluse se javljaju s novim odnosom prema onostranom, koji je iniciran introduciranjem čistilišta. Ibid., str. 307.

${ }^{152}$ Dubrovačke plemkinje, koje su se kao franjevačke trećoretkinje priključivale zajednici takvih žena (većinom pučanki), nisu bile pod redovničkom stegom, a iako u celibatu, nisu bile izolovane od gradskog svakodnevnog života. Radilo se uglavnom o udovicama. Z. JANEKOVIĆ RÖMER, »Nobel Women in Fifteenth-Century Ragusa«, str. 159.

${ }^{153}$ Reclusorium na Lokrumu, dokumentovan 1296. godine, integrisan je u kompleks poznate benediktinske opatije. N. LONZA, »The houses of recluse (reclusoria)«, str. 304, 306.

${ }^{154}$ Dominikanci su u Dubrovnik došli 1225., a franjevci 1227/28. godine. Z. JANEKOVIĆ RÖMER, »Nobel Women in Fifteenth-Century Ragusa«, str. 159.

${ }^{155}$ V. ĐURIĆ, »Umjetnost«, Istorija Crne Gore 2, tom 2, str. 434; S. Marković, Stanovništvo srednjovjekovnog Bara, str. 825-826.

${ }^{156}$ Cfr.: K. HORVAT-LEVAJ, »Samostan benediktinki sv. Andrije na Rabu«, str. 204.

157 »Soror Dominica de Antibaro potest stare absque contradictione alicuius inferioris in Antibaro cum presbytero Paulo Bincovich, eius consanguineo. Die iulii primo.«; »Soror Dominica tercii ordinis potest stare Antibari et cohabitare cum presbytero Paulo Antibariensi. Die eadem. « Stjepan KRASIĆ, »Regesti pisama generala dominikanskog reda poslanih u Hrvatsku (1392-1600)«, Arhivski vjesnik, god. 17-18, br. 1, Zagreb, 2014. str. 228, 230.

${ }^{158}$ Stjepan KRASIĆ, »Nekadašnji dominikanski samostan sv. Nikole u Kotoru (1266 - 1807)«, Prilozi povijesti umjetnosti u Dalmaciji, god. 28, br. 1, Split, 1989., str. 132.

${ }^{159}$ Cfr.: Ivan OSTOJIĆ, »Susreti između benediktinskog i dominikanskog reda u Hrvatskoj«, Bogoslovska smotra, god. 36, br. 3-4, Zagreb, 1966., str. 703, 704, 705. U ugarskom Vesprimu osnovan je 1240. godine ženski cenobij sv. Katarine, koji je prema pismu pape Alesandra IV. bio benediktinski, ali su redovnice u njemu živjele po ustanovama reda propovjednika, izbjegavši pred Tatarima u Nin. Sredinom 14. vijeka u ninskom cenobiju sv. Marije vodila se žestoka rasprava među redovnicama kojem zapravo redu one pripadaju - benediktinskom ili dominikanskom. Ibid., str. 706.
} 
Neki istoričari smatraju da je samostan sv. Marije u Ninu osnovan kao benediktinski, možda još u 10. ili 11. vijeku, a da je kasnije prihvatio pravilo sv. Dominika, ne odbacivši ono sv. Benedikta. ${ }^{160}$ U Puli, u samostanu sv. Katarine Sijenske, koja je bila dominikanka, benediktinske su živjele od druge polovine 15. vijeka do 1600., a njihova nadstojnica nazivala se priora, kao kod dominikanki. Može se pretpostaviti da su u samostanu prvotno bile dominikanke, koje su se vremenom prometnule u benediktinke. ${ }^{161}$ Godine 1572 . pomrle su sve benediktinke u splitskom ${ }^{162}$ samostanu sv. Marije de Taurello pa je gradsko vijeće zaključilo da se dovede iz Zadra jedna plemkinja dominikanka, koja će opustjelu kuću naseliti i urediti po propisima svojeg reda. ${ }^{163}$ Dubrovačka provincija poslala je 1571. godine u Bar na ispomoć i jednog dominikanca. ${ }^{164}$

Blagdan sv. Andrije apostola ostao je u 16. stoljeću u memoriji građana Bara kao jedan od najtragičnijih događaja. Sveta Stolica je 1512. godine namijenila opatiju sv. Marije Ratačke don Luki Alatoviću iz ugledne gradske porodice, što je 21. novembra 1512. odlučio i mletački Senat, dok je barski potestat Vincenzo Zane i gradsko vijeće Bara, koje su činili plemići, poziciju ratačkog opata odredio svešteniku plemenitog roda. »Poradi toga nastade u gradu velika pobuna. Iste godine, uoči Sv. Andrije, plemići i pučani latiše se oružja, učini se strašno krvoproliće i pogiboše 62 čovjeka s obije strane; a izginulo bi ih i mnogo više da se plemići ne bjehu zbjegli u prvostolnu crkvu sv. Jurja, i ondje se spasili dokle kotorski providur Anzolo Malipiero ne doletje u Bar sa 200 vojnika i ne utiša oluju; ali već bijahu opljačkane mnoge plemićke kuće. ${ }^{165}$ Je li taj događaj imao udjela u kolektivnom sjećanju komune u toj mjeri da bi uticao na određenje kulta ženskog samostana, nije poznatim izvorima posvjedočeno.

Monahinje barskog manastira sv. Andrije (»Monache del Monasterio di m. S.to Andrea«) pominju se u izvoru od 13. maja 1570. godine. ${ }^{166}$ Njihov je samostan raspolagao značaj-

${ }^{160}$ I. OSTOJIĆ, »Susreti između benediktinskog i dominikanskog reda«, str. 706-707. Za turske opsade Šibenika 1647. godine benediktinke sv. Lucije prebacile su se na ostrvo Prvić i sklonile u samostan franjevaca trećeredaca. Benediktinke sv. Marije u Zadru primile su deložirane klarise iz zadarskih samostana sv. Nikole (1798.) i sv. Marcele (1807.). Benediktinke sv. Marije na Krku prihvatile su 1806. godine klarise iz ukinutog samostana u Krku. Ukidanjem samostana sv. Justine u Rabu od strane francuske uprave 1807. godine, benediktinke su iz njega otjerane 1809. godine. Jednu od dviju preostalih koludrica primile su franjevke trećoretkinje kod sv. Antuna Opata u Rabu. I. OSTOJIĆ, »Dodiri između benediktinske i franjevačke ustanove«, str. 41. Potcrtao S. M.

${ }^{161}$ Zadarske benediktinke stare opatije sv. Nikole prešle su 1260. godine u klarise. I. OSTOJIĆ, »Susreti između benediktinskog i dominikanskog reda«, str. 707.

${ }^{162}$ Posljednja opatica raspršenih redovnica sv. Benedikta u Splitu pokopana je 1810. godine u samostanu splitskih klarisa. I. OSTOJIĆ, »Dodiri između benediktinske i franjevačke ustanove«, str. 41.

${ }^{163}$ Dva duhovna reda nisu samo jedan drugog nasljeđivali, preuzimajući upravu slabo nastanjenih ili opustjelih samostana, već su se međusobno i pomagali. Dominikanski red je poprimio mnogo samostanskih običaja od benediktinskih opatija. I. OSTOJIC, »Susreti između benediktinskog i dominikanskog reda«, str. 708, 711.

${ }^{164}$ S. MARKOVIĆ, Stanovništvo srednjovjekovnog Bara, str. 826.

${ }^{165}$ Savo MARKOVIĆ, »Izvještaj potestata Andrije Cappella o građanskim nemirima u Baru 1512. godine«, Istorijski zapisi, god. 72, br. 1-2, Podgorica 1999., str. 187; Ivan MARKOVIĆ, Dukljansko-barska metropolija, Zagreb, 1902., str. 126 (na osnovu itinerara mletačkog sindika za Dalmaciju Giovannija Battiste Giustinianija iz 1553. godine).

${ }^{166} »$ Presbyter Franciscus de Antibaro capellanus monasterii S. Andree« sačinio je oporuku u Dubrovniku 10. novembra 1562. Prezviter Frano iz Bara (»don Francesco di Dominico Antibarano, habitante in Raugio«) bio je kapelan benediktinskog ženskog samostana sv. Andrije u Dubrovniku i duhovni otac tamošnjih časnih sestara. Savo MARKOVIĆ, »Povjesnica ecclesice collegiatce S. Petri Antibarensis«, Croatica hristiana 
nim posjedima. ${ }^{167}$ Barski patricij, sveštenik Ivan Župan (pre Zane Zupan), ostavio je 24. septembra 1572. redovnicama sv. Andrije, testamentom prethodno sačinjenim u Dubrovniku, jednu zemljišnu parcelu (polje) koju je kupio od krznarke Krtine, sa stablima maslina i smokava, s tim da se postaraju da se godišnje »otpjevaju« tri mise za duše njegovih nećaka, a zavještava im i kuću koju je kupio od Đorđa Grkovića iz Tuđemila, pod uslovom »da daju da se održe tri mise godišnje u samostanu sv. Andrije i još onoliko koliko se njima učini shodnim ${ }^{168}$. Svakako su te nekretnine darivane redovnicama, koje su mogle iznajmljivati, trebale donositi značajan prihod opatiji.

Veronski biskup Augustin Valier (1531. - 1606.), apostolski pohoditelj dalmatinskih biskupija, boravio je između 5. i 17. marta 1579. u Kotoru i Budvi, gdje ga je posjetio arhiđakon barskog prvostolnog kaptola i upravitelj Barske nadbiskupije. ${ }^{169}$ Upravitelj i delegirani pohodilac Barske nadbiskupije Blaž Baptalea je prije ili 14. juna 1579., na samom kraju vizitacije, posjetio crkvu koludričkog samostana sv. Andrije, kojim je tada upravljao jedini barski franjevac ${ }^{170}$ Frano. ${ }^{171}$ Koludrice su radi lične bezbjednosti bile prisiljene da se vrate svojim kućama, čuvajući nešto od svojih pokretnosti i pokretne imovine opljačkanog i porušenog franjevačkog samostana sv. Nikole (koji je bio pretvoren u štalu), dok su njihov samostan zauzeli »varvari«, kaže vizitator. ${ }^{172}$ S. Kovačić pretpostavlja da su se koludrice vratile svojim kućama zacijelo već 1571 . godine. ${ }^{173} \mathrm{Na}$ osnovu izvoda iz izvještaja barskog patricija i arhiđakona Battaglie ne saznaje se kakva je sudbina zadesila pohođenu crkvu sv. Andrije (je li desakrirana), ali se zaključuje da je njihov samostan već u junu 1579. bio zauzet.

Možda su koludrice u samostanu sv. Andrije ipak opstale koju godinu duže nakon prijelomne 1571. godine. Makar je to preko svojeg muža Antuna Boriša, koji je odžavao intenzivne kontakte s Barom i obavljao službu kancelara, ${ }^{174}$ možda mogla znati njegova žena, $\mathrm{u}$

periodica, god. 42, br. 81, Zagreb, 2018., str. 33-34, 40-41; Vinicije B. LUPIS, »Iz prošlosti srednjovjekovnog zlatarstva u Baru«, Hrvatsko-crnogorski dodiri / crnogorsko-hrvatski dodiri: identitet povijesne $i$ kulturne baštine Crnogorskog primorja, Lovorka ČORALIĆ (ur.), Zagreb, 2009., str. 740.

${ }^{167} \mathrm{Da}$ su posjedi donosili značajan dio sredstava od kojih je redovnička zajednica živjela, svjedoči upoređenje sa koparskim samostanom sv. Klare, na prijelazu iz 18. u 19. st., kada su više od $70 \%$ njegovih prihoda činili dohoci od zakupa i najma kuća, skladišta, njiva i drugih nekretnina. Z. BONIN, »Koprski samostan svete Klare «, str. 145.

168 »Item lasso alle ...de (reverende?, prim. aut.) Monache del Monasterio di m. S.to Andrea uno campo, qual comprai da Chertina Pelizera con s. pie di oliue, et s. pie di arbori di figle, con questa tamen (prim. aut.) condition che siano tegnudi di far cantar tre messe all' ano per gli obiti delli miei nepoti, cioe' pre Marino, Nicola, et Giuro. (...) Item lasso la casa quale ho comprato da Giorgi Grecouich di Togiemilli alle Monache di S.to Andrea, con questa tamen conditione che fano dir ogni anno in perpetuum a S.to Andrea tre messe et tanto, quanto a'loro parera.« V. B. LUPIS, »Iz prošlosti srednjovjekovnog zlatarstva u Baru«, str. 741.

${ }^{169}$ Slavko KOVAČIĆ, »Apostolska vizitacija Barske nadbiskupije 1579. godine«, Znanstveni skup »Fra Šimun Milinović (1835. - 1910.), Povijesne okolnosti i djelo« (knjižica sažetaka), Split, 2010., str. 13.

${ }^{170}$ U Dubrovniku je sačuvan testament od 26. juna 1585. koji je dao sastaviti prezviter Frano Pavlov Baranin (»Presbyter Franciscus Pauli Antibarensis«). DADU, TN, ser. 10. 1., sv. 46, ff. 246v-247r.

${ }^{171}$ S. KOVAČIĆ, »Apostolska vizitacija Barske nadbiskupije 1579. godine«, str. 14.

${ }^{172}$ Ibid., str. 14.

${ }^{173}$ Upoređenja radi, Valierova vizitacija bilježi da je 1579. u samostanu sv. Andrije na Rabu živjelo trinaest redovnica i sedam novakinja, kojih se ukupan broj prema hronici iz 1636. godine popeo na 52. U samostanu su 1866. godine bile samo dvije redovnice. K. HORVAT-LEVAJ, »Samostan benediktinki sv. Andrije na Rabu«, str. 201, 203.

${ }^{174}$ DADU, TN, TN, sv. 47, f. 188v. (21. novembar 1587.). 
Dubrovnik iseljena Katarina, rođ. Dalmas. Catharina Borisc izjavu posljednje volje dala je zabilježiti 2. oktobra 1574. u svojem dubrovačkom prebivalištu. ${ }^{175}$

Posebno osjećanje obilježavalo je smiraj Katarinina života. Želja za oslobođenjem rodnog grada, za koje je bila spremna prepustiti trećinu svoje nepokretne imovine dvama njegovim svetilištima, afektivno nadilazi karitativna, odnosno darivanja pro anima: »Item dichiaro se per alcun tempo la misera patria mia d'Antivari venisse recuperata da christiani, che si dia subito terza parte di tutto mio stabile alla chiesa di Santo Andrea et di Santo Giorgi in Antivari che si prega Iddio per l'anima mia et di miei morti in perpetuum. «176 Pokornički karakter Katarinina zavještanja odnosio se na spasenje njene, i duše njenih preminulih invociranih u molitvama, koje su trajno imali održavati i izgovarati duhovnici katedrale njenog porobljenog zavičaja i koludrice ženskog samostana Sv. Andrije. ${ }^{177}$

Opisujući jadno stanje Katoličke crkve u Baru nakon pada pod tursku vlast, ser Biasio Bataia archidiacono Antivarino, 1579. godine navodi: »Poslije rata je u navedenom manastiru (sc. ratačkom) postavljen jedan župnik, koji je stalno služio u crkvi i bio plaćan od opata, kojem je od vrhovnog pontifeksa bila dodijeljena ta opatija i tako je trajalo do 1571., 4. avgusta, kada je nekadašnji sultan ratovao s mletačkom gospodom, i pod navedenim danom i godinom zadobio grad Bar prepušten od Alexandra Donata, tadašnjeg potestata, a manastir je bio uništen i srušen s crkvom i opatija bila prodata od sultanovog emina; zato se sada ne drži misa niti ikakva Božja služba usljed naših grijeha, zbog kojih je Božansko veličanstvo željelo izvršiti svoju pravednu presudu nad nama. « ${ }^{178}$ Navedene riječi kao da na svoj način evocira i barski nadbiskup Marin Bizzi 1610. godine, u propovijedi vjernicima prilikom prve posjete Baru: »Zatim sam dao obznaniti oproštaj od grijeha, (...) s napomenom da treba strpljivo da podnose ropstvo u koje su pali možda zbog toga što nisu znali dovoljno cijeniti dobročinstva koja su prije primali od Boga uživajući ovako divan i plodan kraj s toliko prostranstva i da je Bog uvijek pripravan da promijeni odluku i da oprosti kad odlučimo da promijenimo način života. ${ }^{179}$

B. Hrabak navodi da je 1613. godine, vjerovatno u dubrovačkom izvoru, zabilježen »manastir Klarisa u Baru, koji je, zajedno sa dubrovačkim manastirima, imao potraživanja od imovine jednog darodavca koji je izvjesne svote zavještao kao legate ${ }^{180}$. Nadbiskup

\footnotetext{
${ }^{175}$ DADU, TN, 10. 1, sv. 44, f. 79v.

${ }^{176}$ Savo MARKOVIĆ, »Posljednja od barskog patricijskog roda Dalmas: »Catharina Borisc, herede universale del q. m. Antonio Dalmas«, Arhivski zapisi, god. 22/2015, br. 1, Cetinje, 2016., str. 64-65, 71. O perpetuiranju godišnjica i hebdomadalnih misa cfr.: Sandrine VICTOR, »Le prix de la mort à Gérone aux XIVe e XVe siècles d'après les actes de la pratique«, Mediterranean Chronicle, vol. 4, Diavlos, Corfu, 2014., str. 75-100; »Contrairement à l'Avignonnais, la pratique de l'anniversaire perpétuel semble se prolonger tout au long de XVe siècle en Catalogne.« Ibid., str. 84.

${ }^{177}$ S. MARKOVIĆ, »Posljednja od barskog patricijskog roda Dalmas«, str. 65. Idem, Stanovništvo srednjovjekovnog Bara, str. 806-807.

${ }^{178} \gg$ Prijepis gorenavedene dotacije je ekstrahiran iz druge slične od mene g. Blaža Battaglie, barskog arhiđakona.« Šime LJUBIĆ, »Rukoviet jugoslavenskih listina«, Starine, JAZU, knj. 10, Zagreb, 1878., str. 1-3.

${ }^{179}$ Ibid.

${ }^{180}$ Bogumil HRABAK, »Pod turskom vlašću«, Bar grad pod Rumijom, Nikola DAMJANOVIĆ (ur.), Bar, 1984., str. 63.
} 
Marin Bizzi u izvještaju od 11. decembra 1618. godine konkretnije bilježi: »Erant in Civitate Moniales S(anc)ti Andreae ordinis S(anc)ti Benedicti, quae in principio passate calamitatis, male inter barbaros securae quaedam Ragusium, et Cattari perfugiunt « (»U gradu su se nalazile redovnice sv. Andrije reda svetog Benedikta, koje su odmah izbjegle opasnost i nesigurne među barbarima, pobjegle u Dubrovnik i Kotor «). ${ }^{181}$ Od zabilješke barskog nadbiskupa Bizzija iz 1618. do zabilješke nadbiskupa Giorge iz 1697. godine nad tom crkvenom ustanovom nadvio se zaborav. Vjerovatno se pozivajući na Bizzijev podatak, a navodeći da su se u gradu nalazili crkva i Zbor koludrica, Farlati i Coleti pišu (1817.): »In urbe Ecclesia \& collegium Virginum Ordinis Benedictini erat«. ${ }^{182}$ Možda je u istoriografiji došlo do konfundiranja tog sa samostanom strogog kontemplativnog reda klarisa. ${ }^{183}$ Treba istaći da su 1589. g. dvije sestre Viktora Besalija (rođenog sredinom 16. vijeka), kćerke Camilla i Paole Prokulijan (iseljene u Dubrovnik 1580. godine), bile redovnice. ${ }^{184}$ Virginia je bila benediktinka, a Benedicta franjevka. Kod pretpostavke da li je taj samostan bio utemeljen za plemkinje, upoređenja radi, djevojčice iz bogatih patricijskih porodica na Rabu vaspitavane su u ženskom benediktinskom samostanu posvećenom sv. Andriji. ${ }^{185}$

Na području Dubrovnika zabilježeni su istoimeni samostani. »Od ostalih crkava valja svakako spomenuti lokalitet Na Andriji, tik uz južni dio gradskog zida, jedan od dijelova grada koji je ostao neobnovljen. Tu je postojala crkva Sv. Andrije, koja se prvi put spominje 1226. kada je u njoj utemeljena jedna od najstarijih dubrovačkih bratovština - bratovština drvodjelaca. Uz crkvu se spominje i samostan, a uz crkvu se nalazila i crkvica Sv. Martina. Dio je samostana porušen 1428. radi pojačanja južnoga obrambenog zida, a stara je crkva

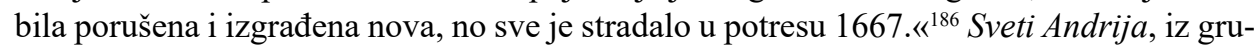
pe Elafita, udaljen je od Dubrovnika $6 \mathrm{~nm}$. Njegovi prvi stanovnici bili su benediktinci, za koje je dubrovačka porodica Crijević izgradila samostan i crkvu. ${ }^{187}$

\footnotetext{
${ }^{181}$ Marko JAČOV, Spisi tajnog vatikanskog arhiva XVI-XVIII veka, Zbornik za istoriju, jezik i književnost srpskog naroda, SANU, II odeljenje, knjiga 22, Beograd, 1983., (prev. dr. sc. Iva KURELEC), Zagreb, str. 33.

${ }^{182}$ D. FARLATI - J. COLETI, Illyrici Sacri tomus septimus, str. 13.

${ }^{183}$ Upoređenje koje se, mada vremenski kasnije, odnosi na redove, govori o vezi klarisa i avgustinki: koparski samostan sv. Klare, ukinut 1806. je g., kada se u njemu nalazilo osamnaest redovnica, koje su se preselile u samostan avgustinki sv. Blaža. Z. BONIN, »Koprski samostan svete Klare«, str. 145.

${ }^{184}$ Testament Prokulijana Camillovog Besalija iz 1589.: »Item reliquit Dominae Virginiae eius sorori in ecclesia Sancti Marci de Ragusio scutos ducentos similes. Item reliquit Benedictae eius sorori in ecclesia Sanctæ Claræ de Ragusio scutos centum similes.« DADU, TN, sv. 48, f. 87r. Savo MARKOVIĆ, »Od Bara i Dubrovnika do Ancone: posljednja volja Prokulijana Camillova Besalija«, Povijesni prilozi, god. 38, br. 57, Zagreb, 2019., str. 47, 59. Svećenik Aleksandar Bazan iz Bara, horist dubrovačke crkve sv. Vlaha (koji je umro 1587. godine), bio je duhovni otac dubrovačkih benediktinki sv. Marka i duhovnik kod franjevki sv. Klare. Savo MARKOVIĆ, »Izjava posljednje volje na kraju jedne epohe - Aleksandar Bazzan«, Istorijski zapisi, god. 90, br. 3-4/2017, Podgorica, 2019., str. 21-39.

${ }^{185}$ Zrinka NOVAK, »Crkvene prilike u Rapskoj biskupiji u XVI. stoljeću«, Croatica christiana periodica, god. 33, br. 64, Zagreb. 2009., str. 16.

${ }^{186}$ Krešimir REGAN - Branko NADILO, »Crkveno graditeljstvo. Ranoromaničke sakralne građevine dubrovačkog područja (II.)«, Građevinar, god. 58, br. 3, Zagreb, 2006., str. 234.

${ }^{187} \mathrm{U}$ taj izolovani samostan se dolazilo uglavnom po kazni Dubrovačke Republike. U potresu 1667. samostan je uništen i poslije nije obnavljan. Sveti Andrija (Elafiti), https://hr.wikipedia.org/wiki/Sveti_Andrija_(Elafiti) (zadnje posjećeno: 17. 5. 2018.).
} 


\section{Zaključna razmatranja}

Samostanski kompleks s crkvom nazvanom sv. Venerande, složene građevinske strukture, u više je navrata bio arheološki istraživan, restauriran i konzerviran. Naslonjen je na fortifikaciju unutar starijeg gradskog jezgra, između komunalnih središta sakralne topografije. Za sv. Andriju apostola i preimenovanje kulta samostanske crkve, koji je zasnivajući se na nesigurnoj tradiciji posvećen pomenutoj svetici, ključni indikator djelo je Vincenza Coronellija iz 1703. godine. Taj autor se, govoreći o lokaciji jedinog gradskog puča, vjerovatno poziva na podatak barskog nadbiskupa Andrije Zmajevića iz 1688. godine. Iako se u kasnom srednjovjekovlju u oskudnim izvorima nailazi na redovnice iz Bara, samostan sv. Andrije se pominje tek u drugoj polovini 16. vijeka. Blagdan sv. Andrije apostola ostao je upravo u 16. stoljeću u sjećanju građana Bara kao jedan od najtragičnijih događaja.

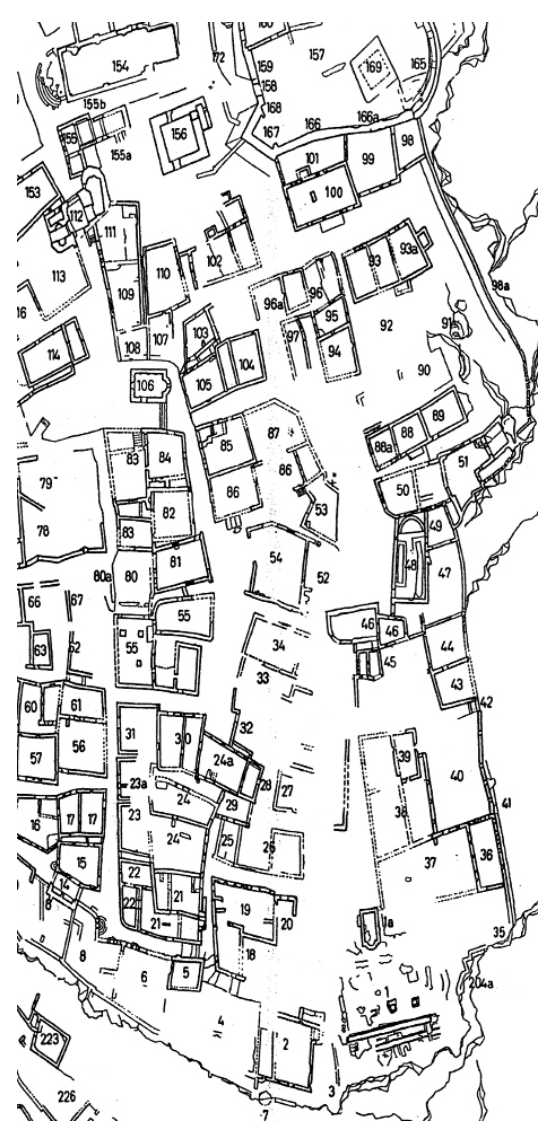

Prema raspoloživim podacima nije poznato ni je li samostan koji se pominje 1570. godine. pripadao samo redovnicama jednog reda, ili jednog staleža, ${ }^{188}$ ali bi dalja istraživanja mogla rasvijetliti ta pitanja. Svakako se aglomeracija sv. Andrije u Baru, smještena na istaknutoj prostornoj poziciji između konfiguracije gradskih zidina (s pogledom na izvangradska redovnička svetilišta), katedralnog i sklopa muškog franjevačkog samostana, povezuje s benediktinkama. Gotički izgled pročelja njegove glavne crkve, interijer, zasebni portali, više prigrađenih i adaptiranih građevina različite namjene, ukazuju na nezanemarljiv imovinski temelj samostana. Prisustvo dumni svjedoči o etabliranom redovništvu, imaginariju i dubinskim slojevima urbaniteta te bi odnosnu sakralnu građevinu trebalo preimenovati shodno novim saznanjima o njenoj istoriji. $U$ vezi sa njihovim pravnim mogućnostima i održavanjem zavičajnih poveznica, egzemplarno su analizirana punomoćja jedne redovnice iz Bara. Konačno, istorijski izvori iz 1579., odnosno 1613. godine, nagovještavaju kako je ugašeno žarište ženske duhovnosti u Baru.

SI. 16. Položaj crkve (br. 48) i samostanskog kompleksa sv. Andrije u starijem dijelu grada, s numeracijom građevina po knjizi Stari Bar (detalj priloga CV)

\footnotetext{
${ }^{188}$ Restriktivna politika komunalnih vlasti prema primanju kandidatkinja u ženske samostane, koja svjedoči o zatvaranju plemićke elite, u Dubrovniku se posebno odnosi na samostan sv. Klare, koji je još od utemeljenja 1290. godine bio namijenjen isključivo plemićkim kćerima. Zdenka JANEKOVIĆ RÖMER, »Zatvaranje dubrovačkog plemstva i vijeća u političkom i društvenom kontekstu 13. i 14. stoljeća«, Anali Zavoda za povijesne znanosti HAZU u Dubrovniku, god. 56, br. 1, Dubrovnik, 2018., str. 95.
} 
Prilog 1. DADU, Diversa cancellarie, sv. 33, fol. 208r. Dubrovnik, 24. jul 1401.

Die XXIIII iullii. MIIIIc primo.

Soror Stana filia condam Luce Mortichiul de Antibaro, reclusa in monasterio Sancti Simeonis de Ragusio, cum consensu et voluntate abatisse et monacharum dicti monasterii confixa de legalitate Mathei Secondini patrui sui de dicta Civitate Antibari omni modo iuris, via et forma quibus melius potuit et potest fecit, constituit et ordinavit eundem Matheum licet abscentem tanquam presentem suum verum et legiptimum procuratorem, actorem, factorem et suorum negotiorum gestorem ac eius nuntium specialem specialiter et expresse in Civitate Antibari et eius districtu, ad petendum, exigendum, et recipiendum quid quid ipsa constituens habere et recipere debet et in futurum debebit a quacumque persona quomodocumque et qualitercumque et tam racionem sucessionis sui patris vel matris quamque racionem omnium legatorum sibi dimissorum in testamentis predictorum patris et matris et omnium alliorum qui dicte constituenti dimisserint per legata et omni alia quacumque racione aut causa et de receptis se vocandum bene solutum et finem, remissionem et absolutionem faciendum omniaque bona tam mobilia quam stabilia dicte constituentis, iura racionis spectanta et pertinentia eidem petendum, salvandum, custodiendum et gubernandum, ipsa bona locandum et dislocandum semel et pluries uni vel pluribus prout dicto procuratori videbitur et placuerit. Quodque si opus fuerit per predictis vel aliquod predictorum ad comparendum coram quocumque judicio tam ecclesiastico quam seculari ad agendum, difindendum libellum, dandum et recipiendum litem et lites contestandum facienti calumpniam et veritatem dicendum in animam et super animam dicte constituentis prestandum et alteri parti dari faciendum et omnia alia et singula que causarum merita postulant a requirunt faciendum, diffendendum et respondendum sumariam et sumarias audiendum et eas executioni mandari faciendum, ab eis appelandum et appelari faciendum, nullitatis et appelacionis causas prosequndum, protestandum et protestari faciendum semel et pluries prout dicto procuratori videbitur et paruerit et qualiter ad omnia et singula alia faciendum, gerendum et procurandum quo in predictis et circha predicta vel aliquod predictorum faciens utilia, necessaria et opportuna, et que ipsamet constituens facere posset si personaliter praesens esset etiam si talia forent que mandatum exiguerent magis (?) speciale: dans et concedens etc., promictens etc.

Ser Marinus de Bodazia iudex et Ser Albertus Bono de civitate Belluni notarius et cancellarius Ragusii testis. 
Prilog 2. DADU, Diversa notariae, sv. 12, fol. 190r. Dubrovnik, 6. oktobar 1417.

Die VI octobris

Soror Stanula filia olim Luce Mortichiuoli de Antibaro et nunc monacha sive claustralis Sancti Simeonis de Ragusio de voluntate et consensu Domine Catarine abbatise dicti monasterii omni modo, iure et forma quibus melius facere potest et potuit, non obstante temporis lapsu per quod Matheus Saguntino de Antibaro cui per fratrem Nicolaum fratrem dicte Stanule locata fuerat ipsi Matheo (cancell.) vinea una quedam et certe terre, sive terrena, de cuius locatione dicta Stanula dixit constare publicum instrumentum quod est apud ipsum Matheum, non solvit affictum dicte vinee et terrenorum propter quod iure poterit priuari dicta locatione prout eadem soror Stanula dixit contineritur in ipso instrumento locationis, confirmavit et roboravit ipsi Matheo $\Lambda$ licet absenti et illi notario presenti et statuenti vice et nomine ipsius ${ }^{189}$ locationem predictam moris, pactis et condicionibus in ipso instrumento locationis contentis, volens quod dictus Matheus amodo in antea habeat, teneat et possideat dictam vineam et cetera que in dicto instrumento continentur sine alicui persone contradictione, molestia vel impedimento; hoc autem etc. Ser Nicolaus Petri de Poza iudex et Ruscus magistri Christofori testis.

In marg.: Extractum

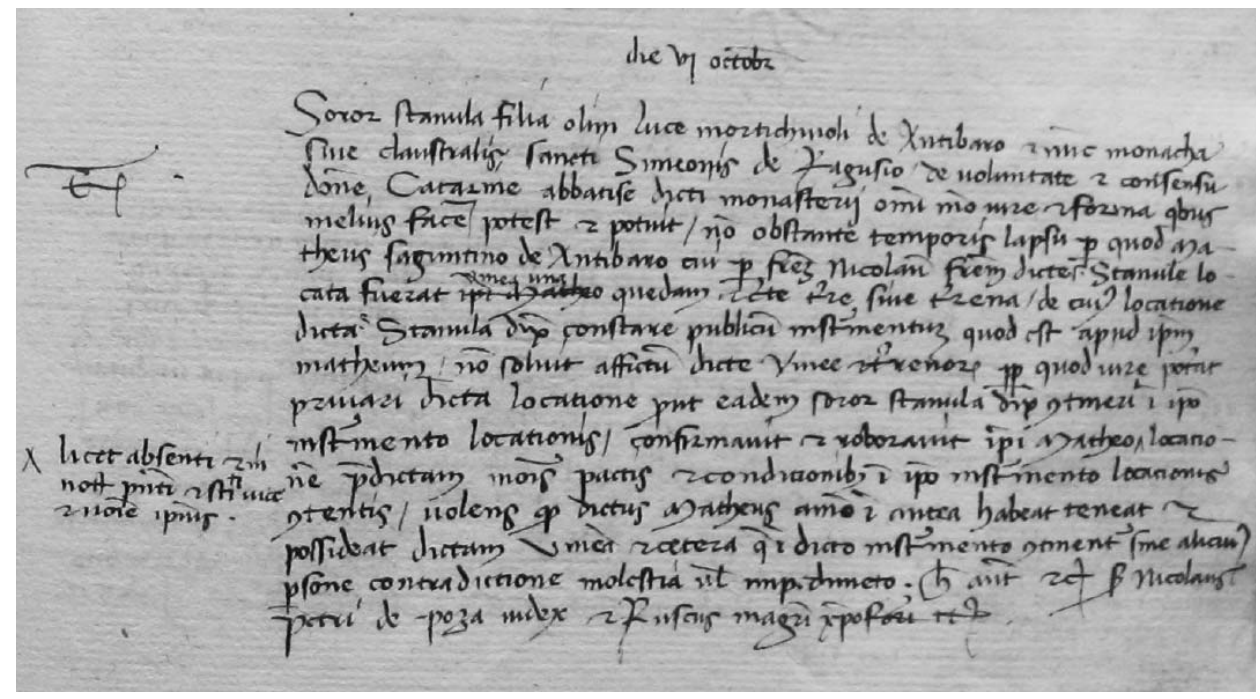

Prilog 3. DADU, Diversa notariae, sv. 12, fol. 191v. Dubrovnik, 25. oktobar 1417.

$\dagger$ MCCCCXVII Indictione Xa. Die XXV octobris

ego Soror Stanula filia olim Luce Martichiuoli de Antibaro et nunc monialis Sancti Simenonis de Ragusio omnia via etc., cassando et revocando alios (!) procurationes habite re-

${ }^{189}$ Vidi se po znaku sličnom $\Lambda$ na koje se mjesto umeće taj tekst. Prim. N. L. 
tro facto,${ }^{190}$ facio et constituo te Nichum filium Mathei de Saguntino procuratorem meum, actorem, factorem et certum nuncium specialem, specialiter pro possessionibus quas teneo hereditarias in Antibaro et eius districtu, comittens tibi licet absenti sed tamquam presenti quatenus meo nomine possis et valeas illas possessiones vel alteram earum locare et dislocare / semel et pluries / et fructus et introitus petere, exigere, recipere et mihi mittere et solicitare quod bene et fideliter laborentur, et de his fructibus quos meo nomine recepis et ad manus meas transmiseris finem et remissionem facere cum solemnitatibus opportunis (a tibi cancell.). Et si opus fuerit in iudicio comparere quot opus fuerit et tibi placuerit agere, causare, petere, excipere, defendere et iura mea prosequi, advocatos et procuratores alios constituere (cancell.) substituere et omnia et singula que ad lites et causas spectant solemniter et efficaciter adimplere, et in animam meam iurare. Et generaliter etc. do quoque tibi in predictis etc. promittens etc. sub obligatione etc. Iudex Ser Nicola Petri de Poza et testis Ruscus magistri Christofori. Et hoc de voluntate domine Catarine abbatisse dicti monasterii presentis et consentientis.

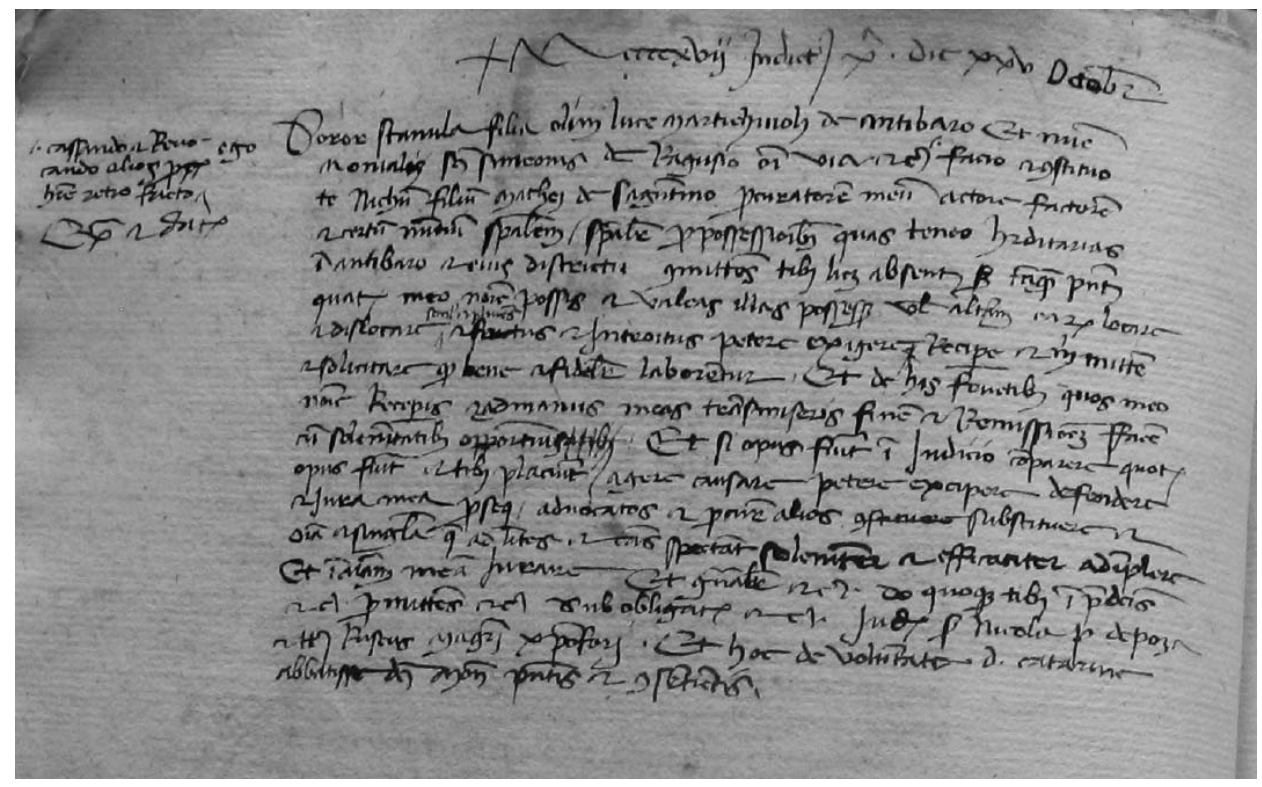

In marg.: ego / a cassando et reucando alioque predicto hinc retrofacto / Extractum et datum.

${ }^{190}$ In marg.: »cassando et revocando alios (!) procurationes habite retro facto«. Umetnuto s margine. 
SUMMARY

MONASTERY OF ST. ANDREW IN BAR (THE $16^{\text {th }}$ CENTURY)

The monastery structure with a church called St. Veneranda, a complex of buildings in Bar, has been archaeologically researched, restored and conserved on several occasions. It rests on a fortification within the older city, between its sacral topography centers. For St. Andrew the Apostle and the renaming of the cult of the monastery church - which is now dedicated to the saint Venera according to an uncertain tradition - a key indicator is the work of Vincenzo Corronelli from 1703. This author, speaking about the location of the only city well, most probably refers to the information of Archbishop of Bar Andrija Zmajevic from 1688. There are scarce sources of nuns from Bar in the late Middle Ages and the monastery of St. Andrew is mentioned only in the second half of the $16^{\text {th }}$ century. Feast of St. Andrew the Apostle remained in the memory of the citizens of Bar in the $16^{\text {th }}$ century as one of the most tragic events. Whether this event had a share in the collective memory of the commune to such an extent as to influence the determination of the cult of the nunnery is not attested by known sources. Also, according to the available data, it is not known whether the monastery mentioned in 1570 belonged only to nuns of one order or one class, but further research could shed light on these issues. It is certain that the agglomeration of St. Andrew in Bar, located in a prominent position between the configuration of the city walls, the cathedral and the complex of the Franciscan monastery, overlooking the out-of-city religious shrines, is connected with the Benedictine nuns. The Gothic appearance of the facade of its main church, the interior, separate portals, several attached and adapted buildings for various purposes indicate a significant property foundation of the abbey. The presence of nuns testifies to the imagery and deep layers of urbanity. The procurations of a nun from Bar were analyzed on an exemplary basis. Finally, historical sources from 1579 and 1613 suggest how the fulcrum of female spirituality in Bar has been extinguished.

KEY WORDS: convent, church, cult, church orders, benedictines, poor Clares, $16^{\text {th }}$ century. 